\title{
Response of macroinvertebrates to experimental nutrient and fish additions in European localities at different latitudes
}

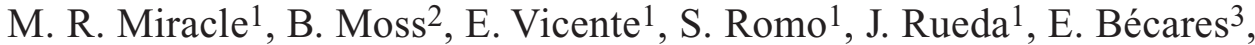 \\ C. Fernández-Aláez ${ }^{3}$, M. Fernández-Aláez ${ }^{3}, J_{\text {. Hietala }}^{4}$, T. Kairesalo ${ }^{4}$, K. Vakkilainen ${ }^{4}$, \\ D. Stephen ${ }^{2}$, L. A. Hansson ${ }^{5}$ \& M. Gyllström ${ }^{5}$ \\ ${ }^{1}$ University of Valencia, Department of Microbiology and Ecology, 46100-Burjassot, Valencia, Spain. \\ ${ }^{2}$ University of Liverpool, School of Biological Sciences, Liverpool, L69 3BX, United Kingdom. \\ ${ }^{3}$ University of Léon, Department of Ecology, Faculty of Biology, 24071 Leon, Spain. \\ ${ }^{4}$ University of Helsinki, Department of Ecological and Environmental Sciences, FIN-15210 Lahti, Finland. \\ ${ }^{5}$ University of Lund, Department of Ecology / Limnology, SE-223 62 Lund, Sweden.
}

\begin{abstract}
The sedimentary and plant-associated macroinvertebrate communities have been examined in a series of mesocosm experiments carried out in five locations, in Finland, Sweden, UK, Northwest Spain and Mediterranean Spain (the International Mesocosm Experiment). The experiments were designed to investigate how shallow lake ecosystems respond to the addition of nutrients and planktivorous fish along a climate gradient.

Nutrient additions increased sedimentary benthos densities and total biomass to a plateau at intermediate levels of nutrients. The effect was greater in the warmest localities. Beyond the saturation point a further increase in nutrient loading had different effects depending on locality. Only in the southernmost site (in Mediterranean Spain), did it induce a shift to a turbid phase and macrophyte disappearance. Thus there are breakpoints in the relationship with nutrients, leading to alternative sediment communities subsequent to the water alternative states. Presence of fish increased the densities and biomass of sediment macroinvertebrates, more clearly in the more southern locality, where the fish Gambusia did not prey in the bottom animals. A stabilising role of macrophytes was observed by cutting them, samples taken three weeks after cutting indicated a higher effect of fish on the sediment community when macrophytes were not present.

Nutrients tended also to increase densities of plant associated macroinvertebrates at low levels with a flattening of response at intermediate levels and a decline at high levels. At high fish level the numbers and biomass of plant-associated macroinvertebrates were lowered in all cases, because of increased predation. However fish addition at low level in most cases had the opposite effect, because their predation pressure was not high and regeneration of nutrients through their activities might increase food availability and control invertebrate predators. Fish influenced especially community composition, because they prey selectively. Addition of fish at low densities increased macroinvertebrate diversity. A diel migratory cycle was observed in plant-associated macroinvertebrates, but only in the southerly locations.

Latitudinal influences on the structure of the macroinvertebrate communities occur but that they operate indirectly. There was a prominent effect of nutrients on these communities so that starting trophy is very important. Fish effects are layered on these and depend to a large extent on the particular range of diet of the species involved.
\end{abstract}

Keywords: Benthos, plant-associated macroinvertebrates, climate gradient, mesocosms, nutrient enrichment, fish predation, shallow lakes.

\section{RESUMEN}

Se ha estudiado la comunidad de macroinvertebrados bentónicos del sedimento así como la de los asociados a los macrófitos en una serie de mesocosmos concebidos para un experimento múltiple simultáneo llevado a cabo en cinco localidades europeas: Finlandia, Suecia, Reino Unido (UK), Noroeste de España y Levante Español. El experimento fue diseñado para investigar como responden los ecosistemas de lagos someros a los aportes de nutrientes y a la abundancia de peces planctívoros a lo largo de un gradiente climático.

La adición de nutrientes incrementó la densidad del bentos del sedimento y su biomasa hasta estabilizarse a niveles intermedios de nutrientes, siendo este efecto mayor en las latitudes más bajas y cálidas. Más allá del punto de saturación, un aumento adicional de la carga de nutrientes tuvo efectos diferentes dependiendo de la localidad y solo en el lugar de menor latitud, (en el Levante Español) indujo el cambio hacia una fase turbia, con desaparición de los macrófitos, esto es, hay puntos de ruptura relacionados con la carga de nutrientes que conducen a comunidades alternativas en el sedimento, subsiguientes a los 
mencionados estados alternativos en las aguas someras. La presencia de peces aumentó la densidad y biomasa de los macroinvertebrados del sedimento, ello también más claramente en la localidad situada más al Sur, ya que el pez planctívoro ensayado (Gambusia) por lo general no depreda en los animales del sedimento. Se observó también el papel estabilizador de los macrófitos comparando las muestras tomadas antes y después de que estos fueran cortados, por ejemplo se observó un efecto mayor de los peces en las comunidades del sedimento cuando los macrófitos no estaban presentes.

Los nutrientes tendieron también a incrementar las densidades de los macroinvertebrados asociados a los macrófitos cuando se aportan a bajos niveles, con una estabilización de la respuesta para los valores intermedios y un declive para los valores más altos. Cuando se adicionaron densidades altas de peces, el número y biomasa de los macroinvertebrados asociados a los macrófitos descendieron en todos los casos, como resultado del aumento de la depredación. Sin embargo, las adiciones a baja densidad de peces, en la mayoría de los casos, tuvo el efecto contrario, ya que su presión de depredación no es alta y pueden contribuir a la regeneración de los nutrientes a través de la vía detrítica que incrementa la disponibilidad de alimento, así como al control de otros invertebrados depredadores. La presencia de peces influenció especialmente la composición de la comunidad, ya que su depredación es selectiva. La adición de peces en bajas densidades aumentó la diversidad de los macroinvertebrados. También fue observado que el ciclo diario de migración en los macroinvertebrados asociados a los macrófitos, es más importante en las localidades ubicadas en las latitudes de más al Sur.

Las influencias latitudinales en la estructura de las comunidades de macroinvertebrados, si bien sucede, opera indirectamente. Hay un efecto dominante de los nutrientes en estas comunidades, y el nivel trófico de las condiciones iniciales es muy importante. Los efectos de los peces se subordinan al de los nutrientes y dependen en gran medida de la dieta de las especies involucradas.

Palabras clave: bentos, macroinvertebrados asociados a macrófitos, gradiente climático, mesocosmos, carga de nutrientes, depredación por peces, lagos someros.

\section{INTRODUCTION}

Benthic animals in shallow lakes are diverse and their communities are strongly influenced by environmental factors, especially trophic state; they have various feeding behaviours including several detritivorous modes and their community composition and diversity are closely involved in functioning of the system through, for example, grazing on periphyton and processing of detritus. Increasing interest has been devoted to benthic community analyses in the estimation of water quality, mainly to cultural eutrophication. However much of the work is descriptive and we do not fully understand the zoobenthos response to either nutrient increase or predatory processes. Since the first findings of increases of benthic invertebrates with nutrient addition in fish culture ponds (Patriarche \& Ball, 1949), other experimental studies have shown the complexity of the problem. Hall et al. (1970) demonstrated that the response of the macroinvertebrate communities to combined fertilisation and predation is highly complex, depending on macrophyte structure and an intricate web of interrelationships with other components of the ecosystem.
The importance of macrophytes in the maintenance of clear water and high biodiversity in shallow lakes is now well established, mostly through relationships with phytoplankton, but also through interactions between macroinvertebrates, fish, and epiphyton that influence the plant-dominated state (Jeppesen et al., 1998). However the complexity of the interactions precludes finding of simple patterns in experimental mesocosm studies on zoobenthos responses to eutrophication and fish, which may be site-dependent (Sandilands et al., 2000). There is very little information on how benthos may respond to climate gradients.

The macroinvertebrate community, both in the bottom sediment and among the macrophytes was examined in homologous experiments carried out in five locations of different latitudes from Finland to Spain. This study is the part of the IME (International Mesocosm Experiment) project, which sought to examine the effects of additions of nutrients and planktivorous fish to in-situ experimental mesocosms along a European climatic gradient (Stephen et al., 2004a, Moss et al., 2004). Treatments included three or five levels of nutrient enrichment to emulate mesotrophic to hypertrophic conditions 
and to test the resistance of vegetated shallow lakes to eutrophication, as well as to explore the threshold in nutrient enrichment that could determine a switch from clear-water state to turbid state. On the other hand the two zooplanktivorous fish addition levels were selected to represent the fish stocks characteristic of eutrophic turbid waters and a low fish density under which zooplankton may still escape fish control and thus regulate phytoplankton (McQueen et al., 1986). Results from these experiments focused on the plankton community have been already published (Moss [ed.] 2004). The present paper gives an overview of the responses of macroinvertebrate communities to the above mentioned treatments. In the case of sediment macroinvertebrates the effect of macrophyte exclusion was also examined in 1998, by cutting them after five weeks of the experiment and continuing treatment thereafter. For plant associated macroinvertebrates the influence of fish on their day-night distribution was also analysed.

\section{METHODS}

\section{Experimental design}

Sets of 36 cylindrical mesocosms were placed in macrophyte-dominated shallow waters (1m deep) at several European locations along a latitudinal gradient. Mesocosms enclosed a column of water of $1 \mathrm{~m}$ in diameter $\left(0.79 \mathrm{~m}^{2}\right.$ area, approx. $750 \mathrm{~L}$ volume at the initial water level) open to bottom sediment and natural vegetation. They were made of transparent polyethylene $(0.125 \mathrm{~mm}$ thick) cylinders mounted (top and bottom) on plastic hoops. The bottom hoop was weighted and sunk into the sediment, at least $20 \mathrm{~cm}$. Mesocosms were held suspended above the water surface by attaching the top hoop to a framework constructed in three blocks of 12 in 1998 and two blocks of 18 in 1999. Their location was moved within the area between years. If necessary, electric fishing was applied before the experiment to remove any fish from the mesocosms. The experiment was performed from the beginning of June to the beginning of August in 1998 and started some weeks later in 1999 depending on the locations (from the middle-end of June to beginning of August). Details of the experimental set-up and methods are given in Stephen et al. (2004a).

The experiments in each location followed a factorial design with two factors, nutrient and fish additions and their interaction. In 1998 it comprised three replicates of twelve mesocosms with combinations of four nutrient levels (N0: no additions and N1 to N3 with weekly loadings to have final added concentrations of $\mathrm{PO}_{4}{ }^{-}$ $\mathrm{P} / \mathrm{NO}_{3}-\mathrm{N}$ of $0.1 / 1,0.5 / 5,1 / 10 \mathrm{mg} \mathrm{L}^{-1}$ respectively) and three densities of planktivorous fish (F0: no fish and F1, F2 with 4 and $20 \mathrm{mg} \mathrm{m}^{-2}$ of fish respectively). The 1999 experiment had two replicates of eighteen treatment combinations of six nutrient levels (N0: no addition and N1 to N5 with weekly loadings, independent of the water level, of $\mathrm{PO}_{4}-\mathrm{P} / \mathrm{NO}_{3}-\mathrm{N}$ of $0.03 / 0.3,0.06 / 0.6$, $0.09 / 0.9,0.15 / 1.5$ and $0.3 / 3 \mathrm{mg} \mathrm{l}^{-1}$ respectively) and the same three fish levels than in 1998.

Data on sedimentary benthos were collected only in the 1998 experiment from four localities, which are ordered by latitude: (i) Lake Vesijärvi near Lahti, Finland (Hietala et al., 2004), (ii) Little Mere near Liverpool, UK (Stephen et al., 2004b), (iii) Lake Sentiz near León, NW Spain (Fernandez-Alaez et al., 2004) and (iv) a lake basin in the Xeresa marshland near Valencia, Mediterranean Spain (Romo et al., 2004). Data on macrophyte-associated macroinvertebrates were collected in the both year's experiments: (1) in 1998 from the same Finish and the two Spanish lakes in which benthos was also studied and (2) in 1999 from these three lakes and also from Lake Krankesjon, in Sweden (Hansson et al., 2004).

The experimental fish added were respectively juveniles of Rutilus rutilus (Finland, 1998 and Sweden, 1999), Perca fluviatilis (Finland 1999) Gasterosteus aculeatus (UK), Chondrostoma (Rutilu) arcasii (NW Spain, both years) and Gambusia affinis (Mediterranean Spain, both years). The Finnish experiment suffered high fish mortality at the two highest level nutrient additions in 1998 and the fish were not replaced for ethical reasons, so that data from the mesocosms 
treated with the two higher nutrient levels and fish addition were only used for nutrient effects analysis and fish effects were evaluated only at the two first nutrient levels.

\section{Sedimentary benthos}

Sediments were taken with a $5 \mathrm{~cm}$ diameter plastic tube, which was pushed into the sediment to a depth of $10 \mathrm{~cm}$. At each location, three replicate samples were collected from each of the thirtysix enclosures and pooled together. The sample was passed through a $400 \mu \mathrm{m}$ net and the retained animals were preserved in $70 \%$ ethanol. Animals were sorted, identified and counted under a stereomicroscope. After counting, the animals were blotted dry and weighed.

Samples were taken at the start of the experiment (during the pre-treatment week, around 9 June) and just after the fifth treatment week (16 July; with the exception of Finland where animals were sampled just after the 4th week, 7 July). Macrophytes were then removed and treatments were continued. A third benthos sampling was taken just after the eighth treatment week (4 August).

\section{Plant-associated macroinvertebrates}

From each of the mesocosms, three (in 1998) or two (in 1999) replicated samples of the macrophytic community were taken using a Kornijów-type sampler (cylindrical box with openings coated with $180 \mu \mathrm{m}$ mesh, Kornijów 1998). The replicates were pooled, to give one sample per enclosure. The sample was shaken in water to dislodge epiphyton and animals. Once small subsamples for epiphyton counts and chlorophyll had been taken and the plant material removed, the water was filtered through a $100 \mu \mathrm{m}$ mesh net. Plant material was further examined and cleaned with water over the 100 $\mu \mathrm{m}$ net to collect any animals left. All animals retained were preserved in $70 \%$ ethanol, sorted, identified and counted under a stereomicroscope. After counting they were blotted dry and weighed. In 1998, samplings were made during the pre-treatment week and after the 5 th week (4th week in Finland) of the experiment, on the same date that for sedimentary benthos in 1998 . In 1999, plant-associated animals were collected in two 24-hour samplings- midday and midnight- during the pre-treatment week (except in Finland where they were collected a week after) and just after the fifth treatment week (7 July-4 August, 23 June-28 July, 28 June-4 August, 17 June-22 July, respectively in Finland, Sweden, NW Spain and Mediterranean Spain).

\section{Statistical analyses}

In all cases a General Linear Model was applied. Estimations and significance of main effects and interactions for the macroinvertebrate variables were determined by univariate analysis of variance (ANOVA) in a two-factor (nutrient, fish), completely randomised design, with three (in 1998) or two (in 1999) replicates in each cell. Although a randomised block design could apply, a completely randomised design was preferred. When day and night samplings were involved, we used a repeated-measures design (three factors: nutrient, fish and time of the day, the latter with repeated measures). In this case we also performed one-way repeated measures ANOVA with time of day as a factor. We used Model III whenever possible and Model IV only in those cases with missing cells owing to some missing samples (i.e. in Krankesjön, plant-associated 1999). Density and biomass data transformed were $1 n$, proportions with arcsine square root and ratios with square root to meet normality and homogeneity of variances requirements.

\section{STUDY SITES}

Table 1 shows the main characteristics of the sites at the time of the experiments. The Finish location is the littoral zone of a large lake (L. Vesijárvi), in a site very near to the shore. At the start of the 1998 experiment it was still so cold that macrophytes had not yet developed and an inoculum of Elodea canadensis (62 $\mathrm{g}$ fresh mass) was added to each mesocosm. Both nutrient enrichment (at all levels) and high fish 
Response of macroinvertebrates to nutrient and fish additions

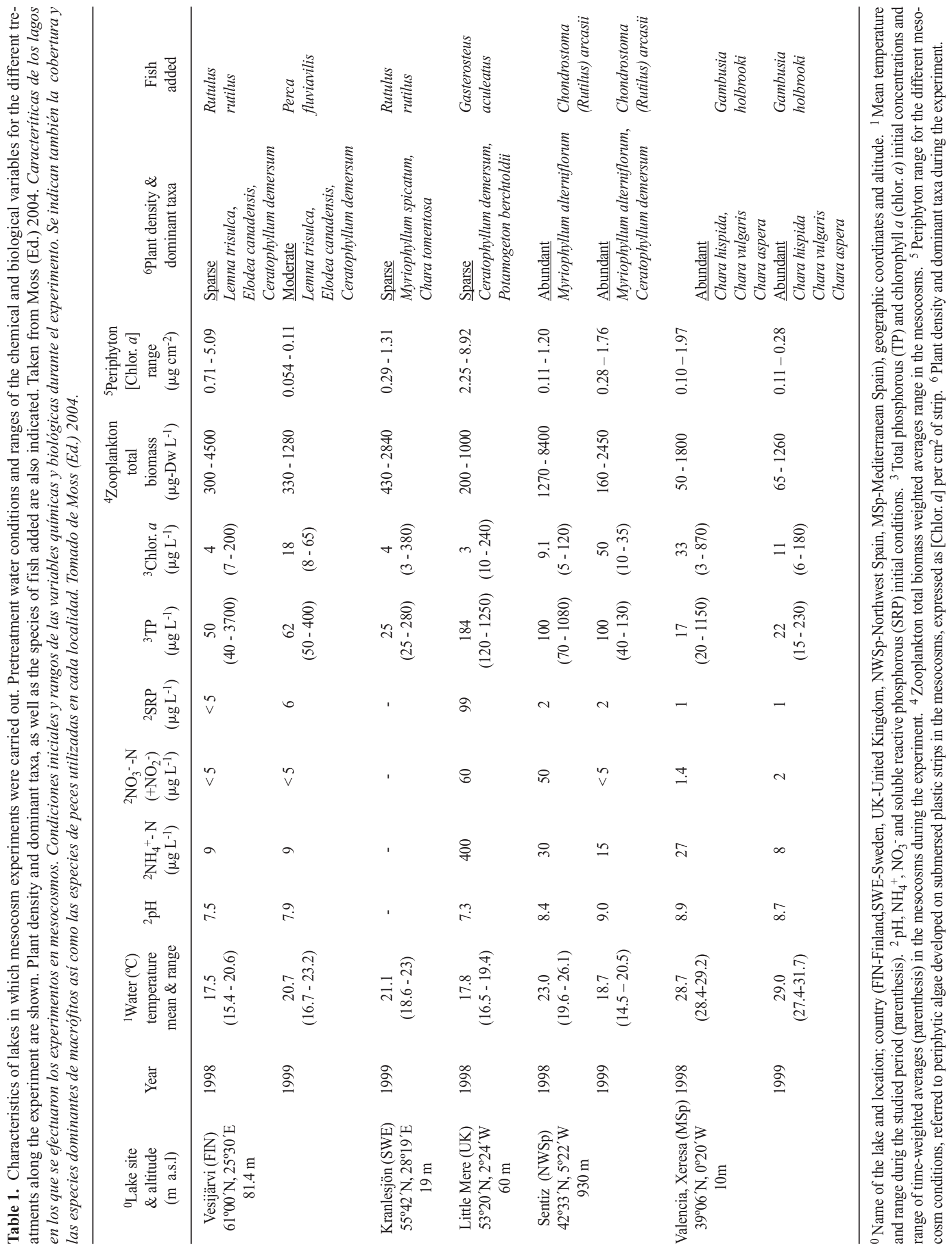


biomass (at the highest level) provoked a decline of submerged macrophytes (E. canadensis, $M$. verticilatum and $P$. natans) and a high increase in planktonic and periphytic chlorophyll; water was very turbid with low Secchi depth $(0.28 \mathrm{~m})$. However the dominant macrophyte was floating Lemna trisulca, which was not significantly affected. Contrarily 1999 was warmer, macrophytes grew well (no inoculum was added) and a clear water state with low chlorophyll prevailed even at the highest nutrient level, which was much lower than in 1998. Floating Lemna trisulca was also the dominant macrophyte in 1999 and accompanying submerged plants E. canadensis and $C$. demersum represented $<10 \%$ of total macrophyte biomass (Hietala, et al., 2004).

The British location, Little Mere, is a eutrophic, small shallow lake, which normally has abundant macrophytes but they were not well developed during the 1998 experiment. Nutrient enrichment produced no significant effects in phytoplankton biomass in this lake because its relatively high pre-treatment nutrient concentrations, but fish additions did increase it. Periphytic chlorophyll increased significantly with nutrients (Stephen et al., 2004).
The Swedish location is the shallow lake Krankesjön. Macrophytes, Myriophyllum spicatum and Chara tomentosa, were sparse in the spring of 1999 and M. spicatum was planted prior to the experiment. Macrophyte densities were low during the experiment and they decreased at high nutrient additions. Phytoplankton and periphytic chlorophyll increased with nutrients and fish, but a clear water state was always maintained (Hansson et al., 2004).

The location in Northwestern Spain, Lake Sentiz, is a small shallow lake with a diverse and dense macrophyte community maintained for long periods, dominated by Myriophyllum alterniflorum, perennial in this lake. The year 1998 was colder than 1999. A strong decline of submerged macrophytes under high nutrient additions was observed in 1998 and 1999 as well, due to strong increments of periphytic chlorophyll. Nutrient and fish additions increased chlorophyll in 1998 and only nutrients had a significant effect in 1999, but the clear water state was maintained in both years in all treatments (Fernández-Aláez et al., 2004).

The Mediterranean Spain location is a very small and shallow water body in a coastal marsh-

Table 2. Relative abundance of main taxa (\%), total density and biomass of sedimentary benthos in four European lakes. Data cover three sampling dates (week 0 -pretreatment-, week 5, and week 8) and are combined for all nutrient and fish treatments in the mesocosm experiments carried out in 1998. Abundancia relativa de los principales grupos del bentos (\%), densidad total y biomasa en el sedimento de cuatro lagos europeos. Los valores son promedios de los 36 mesocosmos con todas las combinaciones de tratamientos, para los tres días de muestreo (antes de los tratamientos (semana 0), a las 5 semanas y a las 8 semanas).

\begin{tabular}{|c|c|c|c|c|c|c|c|c|c|c|c|c|c|}
\hline Location & $\begin{array}{c}\text { Sampling } \\
\text { week }\end{array}$ & Chironomidae & Ephydridae & $\begin{array}{c}\text { Other } \\
\text { Diptera }\end{array}$ & Caenidae & $\begin{array}{l}\text { Other } \\
\text { insects }\end{array}$ & Asellus & Bivalves & Gastropods & Oligochaeta & Hirudinea & $\begin{array}{l}\text { Density } \\
\text { ind } \mathrm{m}^{-2}\end{array}$ & $\begin{array}{c}\text { Biomass } \\
\mathrm{g} \mathrm{m}^{-2}\end{array}$ \\
\hline & 0 & 16 & 0 & *14 & 41 & 10 & 0 & 0 & 4 & 10 & 0 & 510 & 1.6 \\
\hline Vesijärvi & 5 & 50 & 5 & $* 10$ & 5 & 2 & 7 & 0 & 1 & 15 & 3 & 956 & 5.3 \\
\hline \multirow[t]{2}{*}{ Finland } & 8 & 29 & 5 & $* 8$ & 0 & 2 & 9 & 0 & 2 & 42 & 4 & 932 & 5.4 \\
\hline & 0 & 60 & $<1$ & $<1$ & 1 & $<1$ & 3 & 2 & 0 & 32 & 1 & 10314 & 30.1 \\
\hline Little Mere & 5 & 59 & $<1$ & $<1$ & $<1$ & 0 & 3 & 2 & 0 & 34 & 1 & 12511 & 30.4 \\
\hline \multirow[t]{2}{*}{ UK } & 8 & 53 & $<1$ & $<1$ & 0 & 0 & 12 & 2 & 0 & 30 & 2 & 14881 & 50.6 \\
\hline & 0 & 73 & - & - & - & - & 0 & 0 & - & 0 & 0 & 688 & 2.4 \\
\hline${ }^{a}$ Sentiz & 5 & 76 & - & - & - & - & 0 & 0 & - & 0 & 0 & 5039 & 27 \\
\hline \multirow[t]{2}{*}{ NW Spain } & 8 & 73 & - & - & - & - & 0 & 0 & - & 0 & 0 & 3859 & 37 \\
\hline & 0 & present & 0 & 0 & 0 & 0 & 0 & 0 & 0 & present & 0 & 33 & 0.06 \\
\hline Xeresa & 5 & 91 & 0 & $<1$ & 2 & $<1$ & 0 & 0 & 4 & 2 & 0 & 1308 & 2.9 \\
\hline Medit Spain & 8 & 81 & 6 & $<1$ & 2 & 1 & 0 & 0 & 7 & 3 & 0 & 2160 & 5.9 \\
\hline
\end{tabular}

*Mainly Ceratopogonidae. ${ }^{a}$ Quantitative data from Sentiz was only available for Chironomidae and totals (ceros are placed if groups were not recorded) 


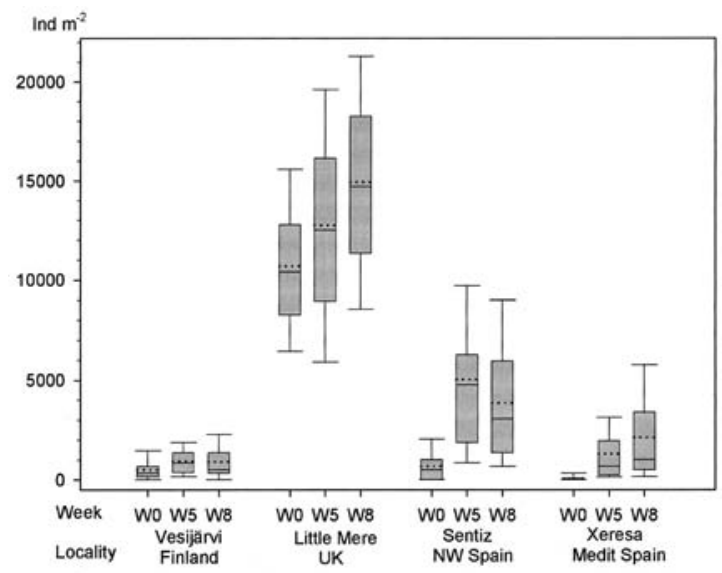

Figure 1. Box plots, with mean (dotted line), median (solid line); quartiles and whiskers (highest and lowest values), of total densities of sediment macroinvertebrates in the 36 experimental mesocosms from each locality for the three sampling weeks in 1998: pre-treatment (week 0), just before macrophytes were cut (week 5) and at the end of the experiment (week 8). Diagramas de caja con media (línea discontinua), mediana (linea continua), cuartiles y bigotes (valores mayor y menor) que representan la densidad de macroinvertebrados del sedimento en los 36 mesocosmos experimentales de cada localidad en los tres muestreos realizados: en el momento previo a iniciar los tratamientos (W0), a las 5 semanas -antes de cortar los macrófitos(W5) y a la $8^{a}$ semana, final del experimento (W8).

land near the town of Xeresa; it was the location with the highest water temperatures and most pronounced water level fluctuations. A dense Chara bed entirely covered the lake bottom in both years. The two highest levels of nutrient additions in 1998 provoked a switch to a turbid state with the loss of macrophytes before the fifth week of the experiment. In 1999 the clear water state was maintained in all treatments because of more moderated nutrient additions were applied and since the water level was lower, the exuberant and dense Chara bed reached the water surface (at the end of the experiment the stalks were even bent floating at the surface) (Romo et al., 2004).

\section{RESULTS}

\section{Sediment macroinvertebrates}

The four shallow lakes were chosen for their comparability and experiments with identical set-ups were run at the same time but fish spe- cies varied and the lakes differed in macroinvertebrate densities and species composition at the start of the experiment, as well as in other characteristics (Tables 1 and 2). For this reason a lake-by-lake approach will be followed to analyse nutrient and fish effects. Figure 1 shows box plots of total numbers per unit area of sedimentary benthic invertebrates at each of the four localities for the pre-treatment week and weeks five and eight. Numbers increased with time only in part due to treatments (this is indicated by the higher variance in weeks five and eight). In correspondence to lake conditions (such as temperature, hydrology, nutrient contents, productivity, sediment type and organic contents) total numbers, biomass and diversity varied among sites. They were by far highest at the productive UK mere (Table 2). The lowest values of these variables were found at: (1) Mediterranean Spain location (M Sp), the smallest and with highest water level fluctuation of the studied lakes that could became dry at the end of summer in some years and (2) the Finnish location, the lake shore of Vesijarvi (FIN), subject also to perturbations because of its littoral location but also for the very low temperatures at start of the experiment. Table 2 shows also how proportions of macroinvertebrate groups differed among sites with a tendency for composition to remain steady with time at all but the Finnish site. Chironomids dominated except in Finland, where other invertebrates were more abundant, particularly Ephemeroptera in the pre-treatment sampling and oligochaetes in the last sampling. The two Spanish sites differed greatly from the two northern sites; they had a poorer fauna consisting mainly of insects, with an absolute dominance of chironomids. Prime distinctions were the scarcity of oligochaetes and the absence of isopods in the sediment samples of the Spanish sites.

The positive relationship between numbers and biomass is shown in figure. 2; it illustrates the expected result that animals are smaller in the southernmost location with higher temperatures and bigger in Finland the coolest site (more conspicuously at low numbers). Means, resulting from the analyses of total biomass and total density, as dependent variables, followed similar 


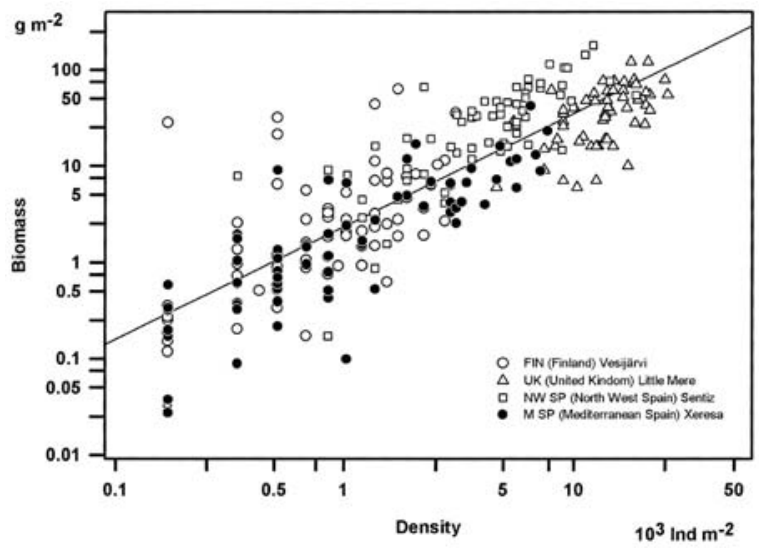

Figure 2. Relationship between total density and biomass of sedimentary benthos from mesocosm experiments carried out at four European localities in 1998. Data from three sampling dates (week 0, week 5 and week 8) Regression statistics with $\log$ transformed data: $\mathrm{b}=1.17, \mathrm{r}^{2}=0.72$. Relación entre la densidad y la biomasa de los macroinvertebrados del bentos para los experimentos en mesocosmos realizados en cuatro localidades europeas. Datos de tres muestreo (semanas 0, 5 y 8 del experimento). Valores estadísticos de la regresión con datos transformados logarítmicamente: $b=1.17, r^{2}=0.72$.

variation patterns when plotted against nutrients and fish, thus only the means of total densities are shown in figure 3 . Because the two sampling weeks (before and after macrophyte removal) yielded different results, they should be examined separately. Results from week 5 for total density and chironomids (Fig. 3, a1, Fig. 4) show that the general response to nutrient additions is an increase of benthic animals with the lowest loading (N1), which levelled off at higher loadings. Beyond this point the increase with nutrients drops and in some cases the highly fertilised mesocosms yielded the same densities or even lower densities than the mesocosms without nutrient addition. The magnitude of the effects differed in the four localities. Little Mere (UK), which had already high nutrient and high benthic density in all mesocosms at the start of the experiment, showed only slight increases. Vesijärvi (Finland) always had very low densities, with a small maximum in the N1 mesocosms. The two Spanish localities showed marked increases with nutrient additions, but whereas in Sentiz (NW $\mathrm{Sp}$ ) there was a typical saturation response, in Xeresa only the lowest level, N1, promoted a high increase, but not the two higher additions, where the number of individuals was lower than in the N0 mesocosms. In Xeresa (Medit Sp) the two high nutrient levels stimulated high phytoplankton growth and death of the submerged Chara bed and its subsequent decay, by the fifth week of the experiment. This could be a factor restricting further colonisation and development of sedimentary benthos in the mesocosms with higher nutrient additions. Results from ANOVAs from each country (Table 3 ) corroborated that, in the two Spanish localities, nutrients had a significant effect on macroinvertebrate total density and biomass but not in the northern sites.

Effects of fish by week 5 were only significant in Finland (owing to problems with fish deaths at high nutrients, so that ANOVA was done only with data from nutrient treatments N0 and N1, Table 3), but in all localities macroinvertebrate densities were higher in mesocosms with fish, with a higher response at nutrient level N1 and a declining effect thereafter (Fig. 2 a2). One reason for lower nutrient effects in the two northern localities is that there was an increase of maroinvertebrate numbers with fish mainly in the mesocosms with lowest nutrients (although the interaction was not significant). This increased the means at nutrient levels, N0 and N1. This effect of fish at the low nutrient addition (N1) was not so clear in the two Spanish sites, where the highly significant effects of nutrients probably masked the effects of fish. To illustrate the above mentioned general tendencies the overall means with the pooled data from all countries are presented in figure 3 a3.

Figure 3 (b1, b2) and figure 4 show results for the eighth sampling week following removal of all macrophytes three weeks previously. There were much more significant effects than previously. Three countries showed significant nutrient effects (Table 3) Little Mere (UK) and Sentiz (NW SP) followed the general saturation response pattern described above. The effect of fish was, contrarily to week 5 , a diminution of macroinvertebrate numbers, because shelter from the plant cover was lost, except for Xeresa (Med SP) where the fish was Gambusia. Xeresa showed also a very different response with nutrients, macroinvertebrates increased greatly in the N3 mesocosms, specially Chironominae and Ephydridae. 

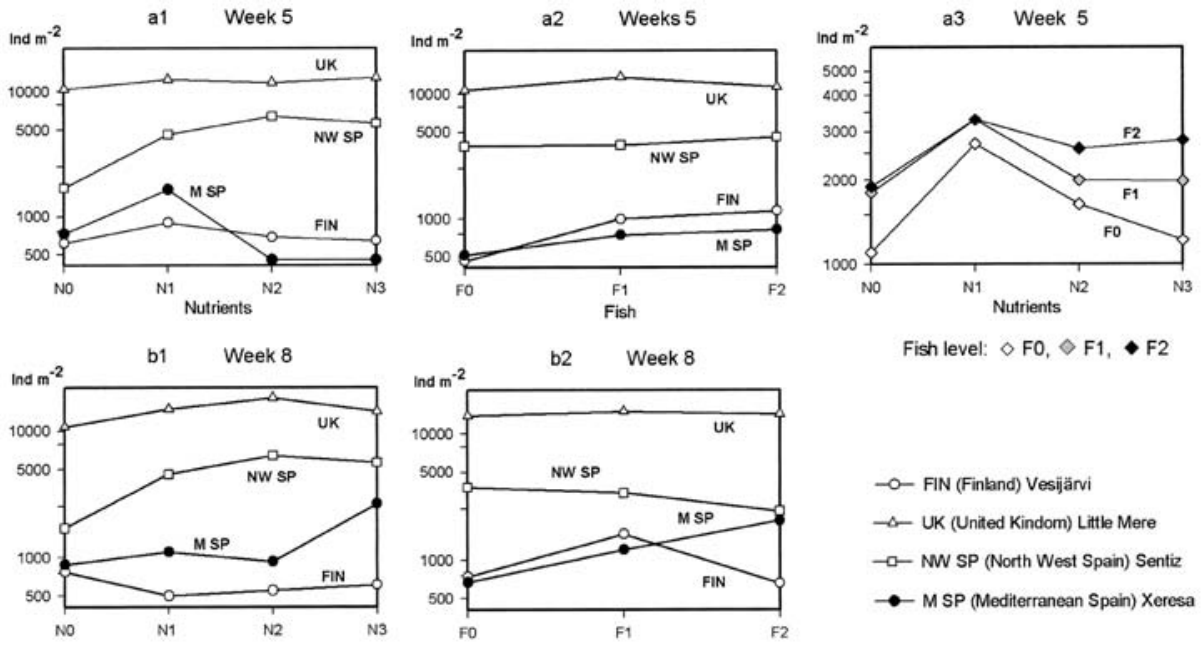

Fish level: $\diamond \mathrm{FO}, \diamond \mathrm{F} 1, \diamond \mathrm{F} 2$

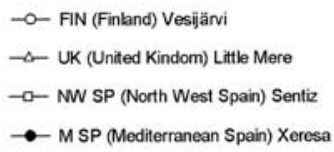

Figure 3. $(a, b, c)$. Means of total sediment macroinvertebrate densities with respect to nutrients and fish treatments in mesocosm experiments carried out in four European localities (log transformed data). a1-a2: means of densities from week 5 for each location; a3: means of densities of pooled data from all locations for each fish level; b1-b2: means of densities from week 8 for each location. Data points for each location are joined and indicated by their corresponding symbol. In a3 data points are joined for each fish treatment. Promedios de la densidad de macroinvertebrados del sedimento con respecto a los tratamientos de nutrientes y peces de los experimentos en mesocosmos realizados en cuatro localidades europeas (datos transformados logaritmicamente). a1-a2: Promedio de las densidades a las 5 semanas para cada localidad; a3: Promedio de las densidades de todas las localidades juntas para cada nivel de peces; b1-b2: Promedio de las densidades a las 8 semanas para cada localidad. Los puntos para cada localidad están enlazados con una línea e indicados por su símbolo correspondiente.

Table 3. Effects of nutrient and fish treatments on macroinvertebrates from mesocosm experiments carried out at four European locations in 1998. Results of univariate two-way ANOVA's run separately for each sampling day (after $5^{\text {th }}$ week and $8^{\text {th }}$ week). Efectos de los tratamientos de nutrientes y peces en los macroinvertebrados del sedimento en los mesocosmos de los experimentos realizados en cuatro localidades europeas. Resultados de los análisis univariados de la varianza de dos factores.

\begin{tabular}{|c|c|c|c|c|c|c|c|}
\hline \multirow[t]{2}{*}{ Response Variable } & \multirow[t]{2}{*}{ Location } & \multicolumn{3}{|c|}{ Week 5} & \multicolumn{3}{|c|}{ Week 8} \\
\hline & & Fish $(\mathrm{F})$ & Nutrients $(\mathrm{N})$ & $\mathrm{F} \times \mathrm{N}$ & Fish $(F)$ & Nutrients $(\mathrm{N})$ & $\mathrm{F} \times \mathrm{N}$ \\
\hline \multirow[t]{4}{*}{ Total Biomass } & Finland & ns & ns & ns & ns & ns & ns \\
\hline & UK & ns & ns & ns & $*$ & ns & ns \\
\hline & NWSpain & ns & $*$ & ns & ns & $*$ & ns \\
\hline & MedSpain & ns & $*$ & ns & ns & $*$ & ns \\
\hline \multirow[t]{4}{*}{ Total density } & Finland & $*$ & ns & ns & ns & ns & ns \\
\hline & UK & ns & ns & ns & ns & $*$ & ns \\
\hline & NWSpain & ns & $* *$ & ns & ns & $*$ & ns \\
\hline & MedSpain & ns & $*$ & ns & & $*$ & $\mathrm{~ns}$ \\
\hline \multirow[t]{4}{*}{ Biomass / Density } & Finland & ns & ns & ns & ns & ns & ns \\
\hline & UK & ns & ns & ns & $* *$ & ns & $\mathrm{ns}$ \\
\hline & NWSpain & ns & ns & ns & ns & ns & ns \\
\hline & MedSpain & ns & $*$ & ns & ns & ns & ns \\
\hline \multirow[t]{4}{*}{ Chyronomid density } & Finland & ns & $*$ & $*$ & ns & $*$ & ns \\
\hline & UK & ns & ns & ns & $*$ & $*$ & ns \\
\hline & NWSpain & ns & $*$ & ns & ns & $*$ & ns \\
\hline & MedSpain & ns & ns & ns & $*$ & $*$ & ns \\
\hline \multirow[t]{2}{*}{ Asellus } & Finland & $*$ & ns & ns & ns & $*$ & ns \\
\hline & UK & $* * *$ & $* *$ & $* *$ & ns & $* * *$ & ns \\
\hline \multirow[t]{2}{*}{ Oligochaeta } & Finland & ns & ns & ns & ns & ns & ns \\
\hline & UK & ns & ns & ns & ns & ns & $\mathrm{ns}$ \\
\hline \multirow[t]{2}{*}{ Oligochaeta/chironomidae } & Finland & ns & $\mathrm{ns}$ & $\mathrm{ns}$ & ns & $*$ & $\mathrm{~ns}$ \\
\hline & UK & ns & ns & ns & ns & ns & $\mathrm{ns}$ \\
\hline Oligochaeta/chironomini & UK & ns & $\mathrm{ns}$ & ns & $* *$ & ns & $\mathrm{ns}$ \\
\hline Chironomini density & UK & ns & ns & ns & $*$ & ns & $\mathrm{ns}$ \\
\hline Tanypodinae density & UK & ns & ns & ns & $* *$ & ns & $\mathrm{ns}$ \\
\hline Bivalves & UK & ns & $\mathrm{ns}$ & ns & ns & ns & $\mathrm{ns}$ \\
\hline
\end{tabular}

$* \mathrm{p}<0.05, * * \mathrm{p}<0.01, \quad * * * \mathrm{p}<0.001, \mathrm{~ns}=$ not significant

In the ANOVAS for Finland only the two nutrient levels N0 and N1 were considered.

(ANOVAS with transformed data, $\ln$ for densities and biomass and sqr for ratios) 
Miracle et al.

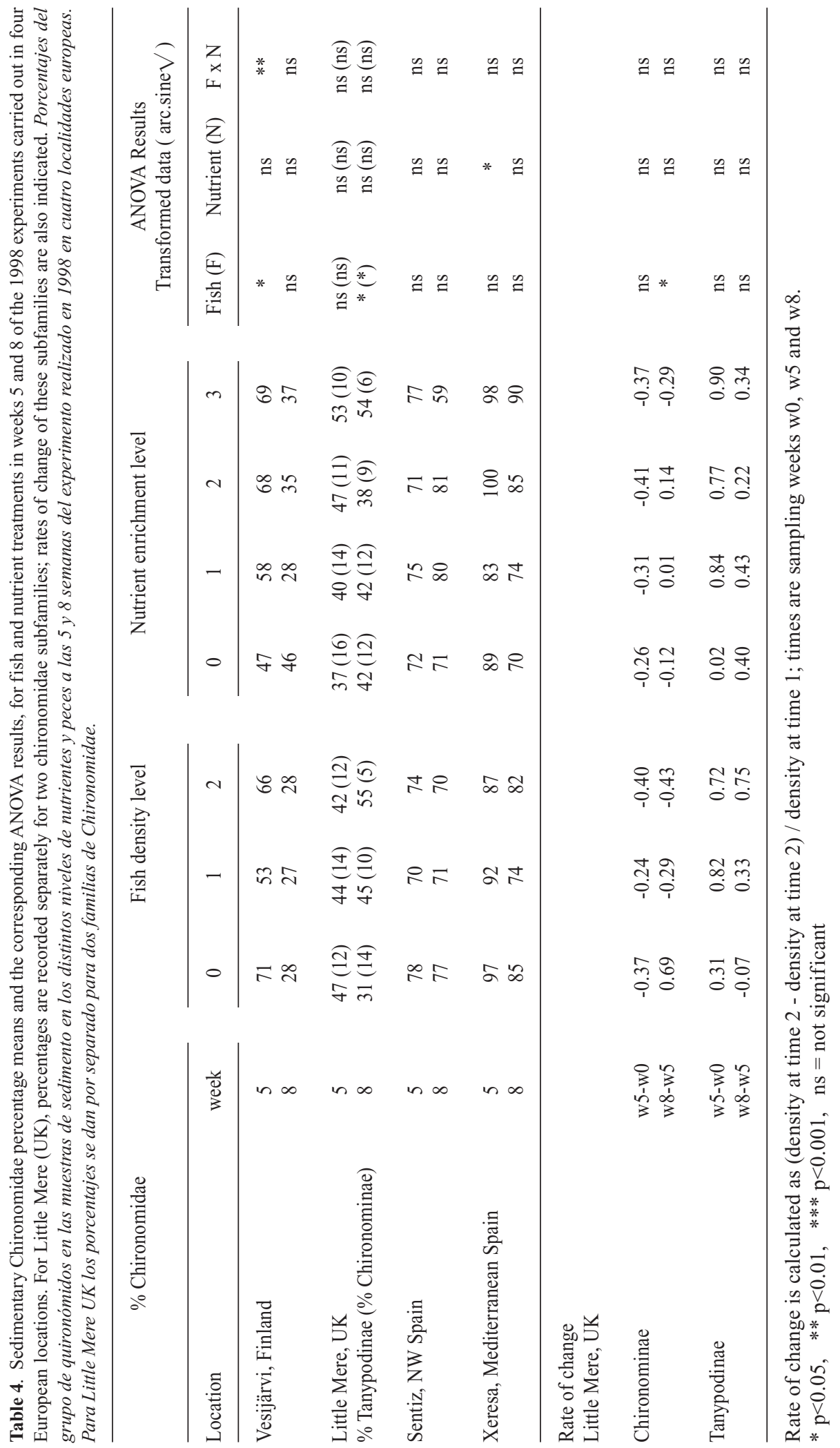




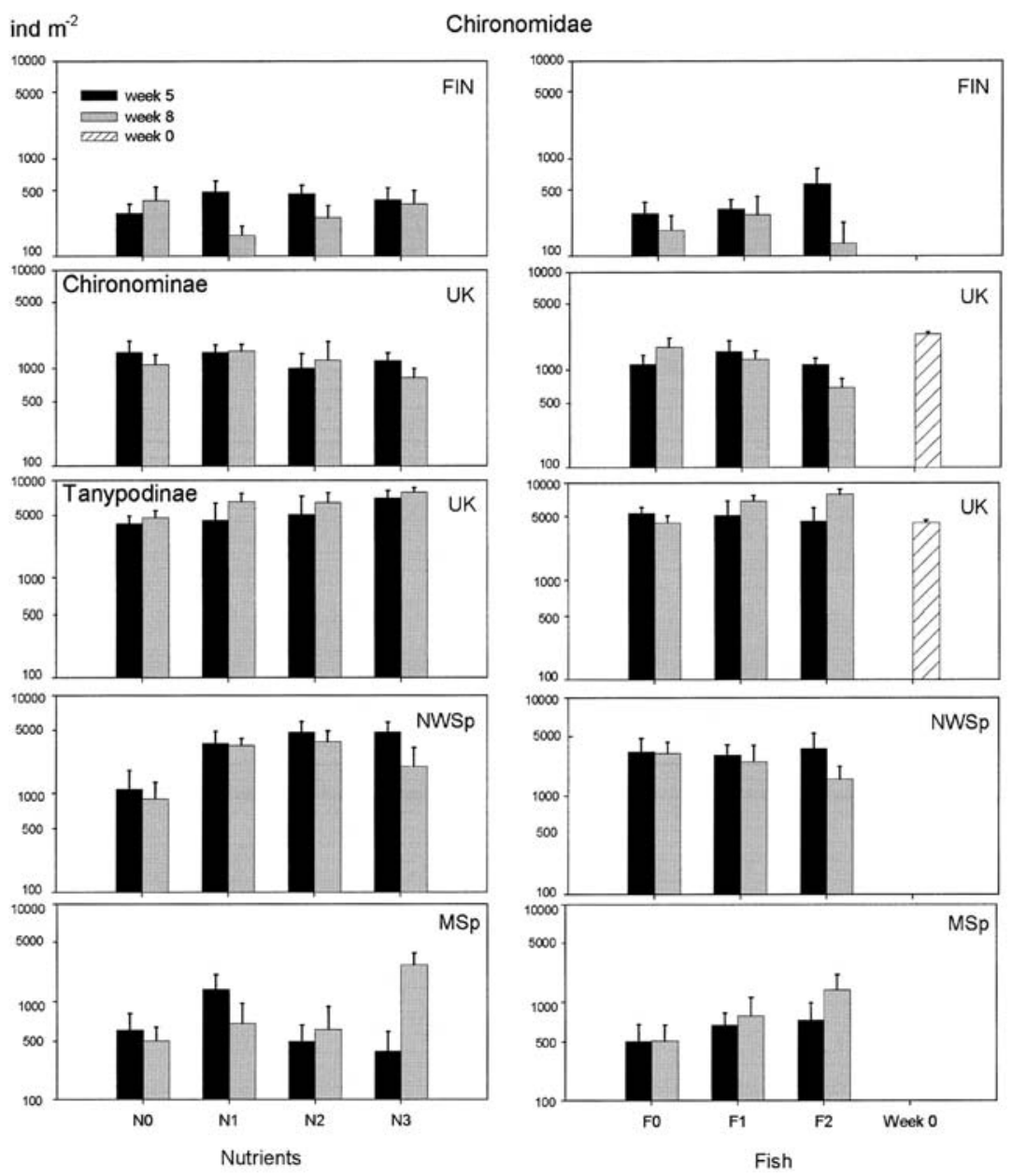

Figure 4. Mean values (SE) of sedimentary Chironomidae densities in each nutrient and fish treatment from two sampling dates of 1998 experiments carried out in four European locations (initials as in Fig.3). Mean values of the 36 mesocosms for the pre-treatment week (WO) are also plotted when $>100$. Data from UK (Little Mere) are plotted separately for chironomidae subfamilies (Chironominae and Tanypodinae). (All data log transformed). Valores medios (ES) de las densidades de los quironómidos del sedimento en cada nivel de nutrientes y de peces en dos muestreos durante los experimentos de 1998 realizados en cuatro localidades europeas (iniciales como en la Fig.3). Los valores medios para el muestreo antes de los tratamientos (W0) se dibujan también si >100. En UK (Little Mere) se han representado separadamente las densidades correspondientes a dos subfamilias de quironómidos (Chironominae y Tanypodinae). (Todos los datos transformados logaritmicamente).

Chironomid percentage (Table 4), which can be taken as an indicator of diversity of the benthic community, in general increased with nutrient addition and decreased with fish. However there were also a number of significant effects when chironomid subfamilies were examined individually (Tables 3 and 4, Fig.4), which make clearer the variations due to removal of macrophytes. Chironomid responses to nutrients or fish (Fig. 4) were broadly similar to those of total numbers. In general Chironominae was the main group of chironomids (in Medit. Spain $93 \%$, in week 5 and $97 \%$, in week 8 of chironomid larvae were from this group), but in Little Mere UK Tanypodinae were more abundant than Chironominae (Table 1, Fig. 4). The high densities of the two groups of chironomids in that site allowed further analyses which made evident the great differences in the responses of these subfamilies (rates of change in numbers were also calculated for each mesocosm and means for treatments are given in Table 4). 
Chironominae numbers diminished from the pre-treatment to week 5 in controls and all other treatments, probably because some individuals reached adulthood and emerged (presence of pupae in some samples supports this), but there was no significant fish nor nutrient effect. However after macrophytes were cut, Chironominae increased in controls and in all the mesocosms without fish (no pupae were detected), but diminished with fish treatments, thus indicating fish predation (Table 4). Contrarily Tanypodinae increased with time and in both samplings their numbers rose with nutrient and fish additions. Chironominae in Little Mere were much bigger $(77 \%$ from $>10$ to $20 \mathrm{~mm}$ and the rest $>20 \mathrm{~mm}$ ) than Tanypodinae $(80 \%$ $<10 \mathrm{~mm}$ and the rest from 10 to $<20 \mathrm{~mm}$ ). This difference in size and also the distinct behaviour of the two types of larvae account for the diffe- rential predation pressure by fish on them. In week 8 , Chironominae were significantly lower with fish additions whereas Tanypodinae were significantly higher (Fig. 4, Table 4). The significant fish effect on total biomass and on biomass per individual detected from ANOVA (Table 2) in week 8 corresponded with the diminution of mainly the larger animals (Chironominae and also Asellus) with fish predation (specially in fish level F2, post hoc Tukey's tests separate F2 significantly from the other levels).

In the two northern lakes where the percentage composition of oligochaetes was important, its variation with respect to chironomids is shown in figure 5. In Vesijarvi (Finland) the ratio Oligochaeta /chironomids increased mainly in week 8 with low nutrient additions and especially in the mesocosms with fish, whereas this ratio did not vary significantly in Little Mere, (UK), (oscilla-
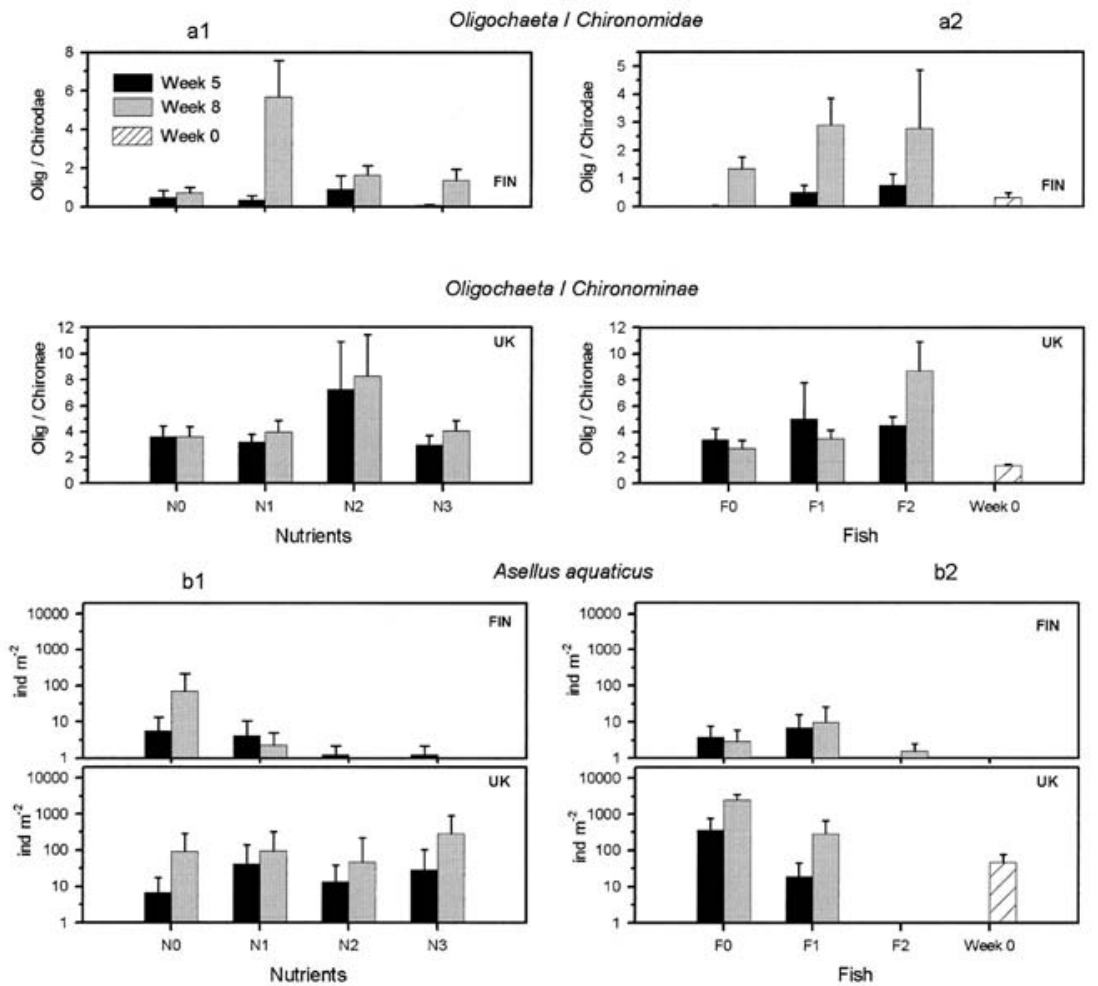

Figure 5. (a) Oligochaeta: Chironomidae density ratio by week with respect to nutrient (a1) and to fish (a2) treatments for Vesijärvi (FIN) and Oligochaeta : Chironominae density ratio for Little Mere (UK). (b) Asellus aquaticus density (log transformed data) by week with respect to nutrient (b1) and fish (b2) treatments for Vesijärvi (FIN) and Little Mere (UK). Razón Oligoquetos:quironómidos (en número de individuos) para cada semana de muetreo con respecto a los niveles de nutrientes (a1) y peces (a2) en Vesijärvi (FIN) y la razón Oligoquetos: Chironominae (en números) en Little Mere (UK). (b) Densidades de Asellus aquaticus (datos transformados logaritmicamente) en cada semana con respecto a los niveles de nutrientes y peces, en Vesijärvi (FIN) y Little Mere (UK). 
ting around a mean of 0.7 , range: $0.6-1$ in week 5 and 0.6 , range: $0.4-0.7$, in week 8 , not plotted). However when subgroups of chironomids are treated separately, the ratio Oligochaeta / Chironominae in Little Mere shows a high increase with intermediate nutrients and with fish addition especially in week 8, as in Vesijärvi.

In Little Mere (UK) significant nutrient and fish effects were found for Asellus populations (Stephen et al., 2004). Asellus was almost completely consumed at the high fish level and drastically diminished with low fish (Fig. 5). Asellus from the Finnish site almost dissapeared also by fish predation at the high fish level. However, at this location, Asellus had a much lower abundance and contrarily to UK was negatively affected by nutrient enrichment, disappearing at nutrient levels N2 and N3; in this location fish died also

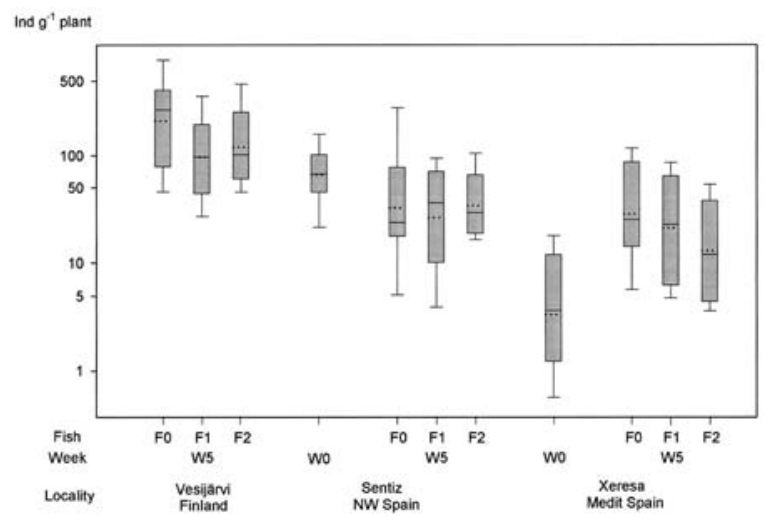

Figure 6. Box plots and whiskers (as in Fig. 1, mean: dotted line, median: solid line) of total densities of plant-associated macroinvertebrates in mesocosm experiments carried out at three European locations in 1998. Data (log transformed) are taken from the 36 experimental mesocosms from each locality for the pre-treatment (W0) and from each fish treatment for the fifth week (W5). Fish treatment were pooled across nutrient enrichment levels ( $\mathrm{n}=6$ for Finland and Mediterranean Spain and $\mathrm{n}=12$ for NW Spain). Diagrama de caja y bigotes (como en la Fig. 1, media: línea discontinua, mediana: línea continua), que representa la distribucion de los valores de la densidad de macroinvertebrados en muestras de macrófitos de los experimentos realizados en tres localidades europeas en 1998. Datos (transformados logaritmicamente) procedentes de los 36 mesocosmos experimentales de cada localidad en dos muestreos: antes de los tratamiento (W0) y para cada nivel de peces en el muestreo a las 5 semanas (W5). Cada nivel de peces comprendia todos los tratmientos de nutrientes ( $n=6$ en Finlandia y la zona del Levante Español y $n=12$ en la zona del NO Español). in these treatments, indicating that survival of some animals may be badly affected by the high nutrient additions in the waters of that lake.

\section{Plant-associated macroinvertebrates}

\section{8 experiment}

Plant associated macroinvertebrates were more diverse than those of the sedimentary benthos, although chironomids also were dominant in all sites. Since plant growth was unusually late in the Finnish site due to weather conditions, macroinvertebrates were not collected in the pre-treatment week. However by the $5^{\text {th }}$ week of the experiment macroinvertebrates were more abundant in the Finnish lake than in the two more southerly lakes (Fig. 6, Table 5) but they showed a lower diversity. Proportions of gastropods and ephemeropterans were very important in the Spanish sites, whereas in Finland only ephydrids had some importance after the dominant chironomids. There was again a significant relationship between densities and biomass, with macroinvertebrates being smaller in the southernmost site (Fig. 7, Table 5).

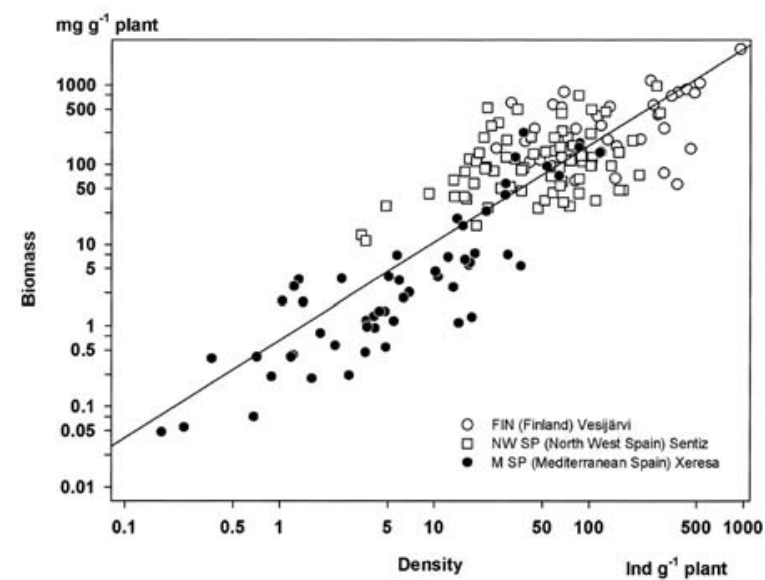

Figure 7. Relationship between total density and biomass of plant-associated macroinvertebrates from mesocosm experiments carried out at three European localities in 1998. Data from two sampling dates (week 0 and week 5). Regression statistics with $\log$ transformed data: $\mathrm{b}=1.21, \mathrm{r}^{2}=0.75$. Relación entre la densidad y la biomasa de los macroinvertebrados asociados a las muestras de macrófitos de los experimentos en mesocosmos realizados en tres localidades europeas en 1998. Datos de dos muestreos (semanas 0 y 5). Valores estadísticos de la regresión con los datos transformados logarítmicamente: $b=1.21, r^{2}=0.75$. 


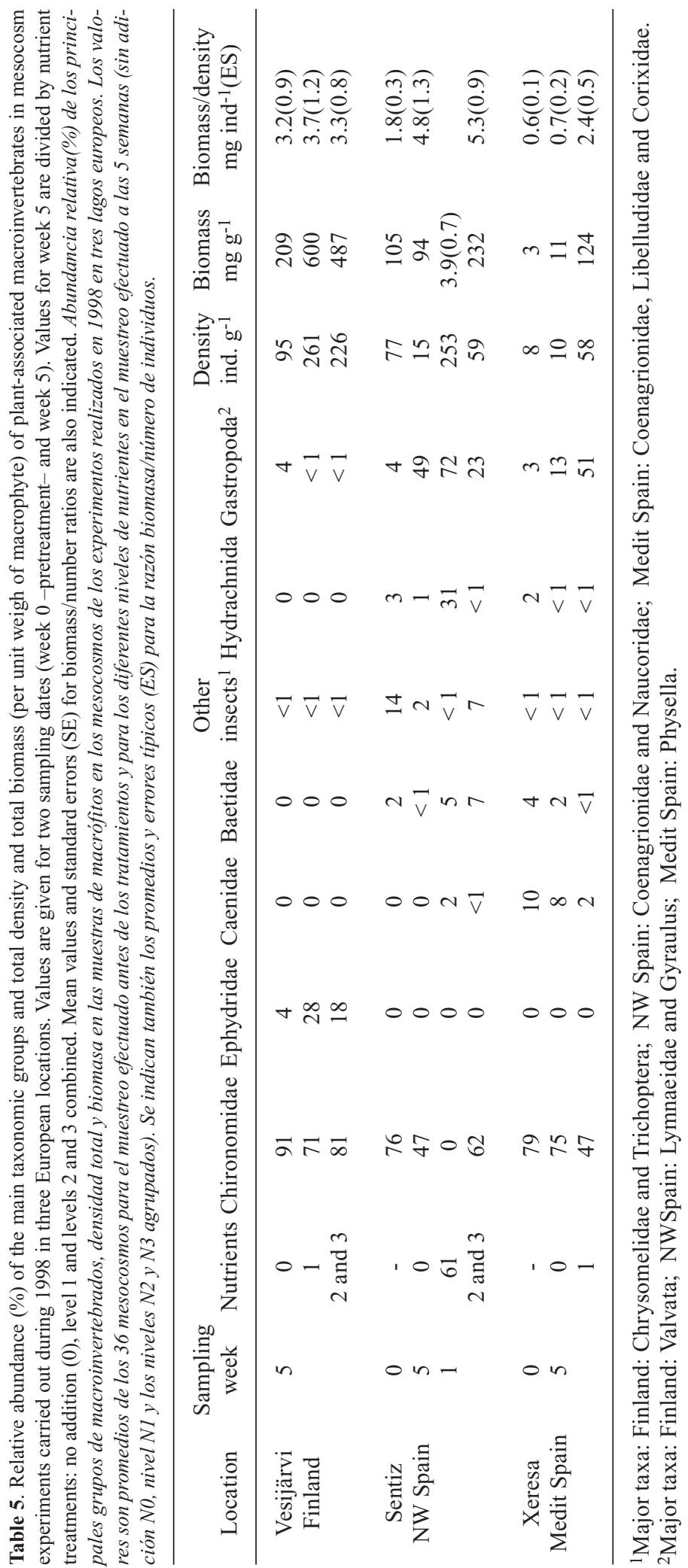


Table 6. Effects of nutrients and fish treatments in determining density, proportions and biomass of plant associated macroinvertebrates in mesocosm experiments carried out in several European locations in 1998 and 1999. Results from univariate two-way ANOVA's, fixed factors fish (F) and nutrients (N) for 1998 and a three-way repeated measures ANOVA (three factors F, N and day/night samplings (D/N), one of them $(\mathrm{D} / \mathrm{N})$ with repeated measures). Efectos de los tratamientos de nutrientes y peces en la densidad, biomasa y proporciones de los macroinvertebrados asociados a macrófitos en los mesocosmos de los experimentos realizados en varias localidades europeas en 1998 y 1999 . Resultados de los análisis univariados de la varianza de dos factores, nutrientes (N) y peces (F) para el experimento de 1998 y del análisis de la varianza de tres factores con medidas repetidas en uno de ellos (nutrientes, peces, distribución díalnoche, con medidas repetidas el último).

\begin{tabular}{|c|c|c|c|c|c|c|c|c|}
\hline \multirow[t]{2}{*}{ Response variable } & \multirow[t]{2}{*}{ Location } & \multicolumn{3}{|c|}{ Univariate ANOVA 1998} & \multicolumn{4}{|c|}{ RM ANOVA 1999} \\
\hline & & $\mathrm{F}$ & $\mathrm{N}$ & $\mathrm{F} \times \mathrm{N}$ & $\mathrm{F}$ & $\mathrm{N}$ & $\mathrm{F} \times \mathrm{N}$ & $\mathrm{D} / \mathrm{N}$ \\
\hline \multirow[t]{4}{*}{ Total biomass } & Finland & * & * & ns & * & ns & ns & nss \\
\hline & Sweden & - & - & - & $*$ & ns & ns & nss \\
\hline & NWSpain & $\mathrm{ns}$ & $* *$ & ns & $\mathrm{ns}$ & $* * *$ & ns & nss \\
\hline & MedSpain & $*$ & $* * *$ & $*$ & $* *$ & $* * *$ & ns & nss \\
\hline \multirow[t]{4}{*}{ Total density } & Finland & ns & $*$ & ns & $* *$ & ns & ns & nss \\
\hline & Sweden & - & - & - & $\mathrm{ns}$ & ns & ns & nss \\
\hline & NWSpain & ns & $* *$ & ns & ns & ns & ns & $* * *$ \\
\hline & MedSpain & ns & $* * *$ & $\mathrm{~ns}$ & $* * *$ & $* * *$ & ns & $* *$ \\
\hline \multirow[t]{4}{*}{ Biomass/Density } & Finland & ns & ns & ns & ns & ns & ns & nss \\
\hline & Sweden & - & - & - & $\mathrm{ns}$ & ns & ns & nss \\
\hline & NWSpain & $\mathrm{ns}$ & * & ns & $\mathrm{ns}$ & $* * *$ & ns & nss \\
\hline & MedSpain & $\mathrm{ns}$ & $* *$ & $*$ & $*$ & ns & ns & nss \\
\hline \multirow[t]{4}{*}{ Chironomidae } & Finland & $*$ & ns & $*$ & $\mathrm{~ns}$ & ns & ns & nss \\
\hline & Sweden & - & - & - & $\mathrm{ns}$ & $\mathrm{ns}$ & ns & nss \\
\hline & NWSpain & $\mathrm{ns}$ & $* *$ & ns & $\mathrm{ns}$ & ns & ns & $* * *$ \\
\hline & MedSpain & $*$ & $*$ & $\mathrm{~ns}$ & $* * *$ & $* * *$ & ns & * \\
\hline Chironomidae & Finland & ns & * & $\mathrm{ns}$ & $*$ & ns & ns & nss \\
\hline \multirow[t]{3}{*}{ Proportion } & Sweden & - & - & - & $\mathrm{ns}$ & ns & ns & nss \\
\hline & NWSpain & $* *$ & ns & ns & $\mathrm{ns}$ & $*$ & ns & $* *$ \\
\hline & MedSpain & * & $* * *$ & ns & $*$ & * & ns & nss \\
\hline \multirow[t]{4}{*}{ Gastropods } & Finland & - & - & - & $* *$ & ns & ns & nss \\
\hline & Sweden & - & - & - & ns & ns & ns & nss \\
\hline & NWSpain & $* *$ & * & ns & $\mathrm{ns}$ & $* *$ & ns & nss \\
\hline & MedSpain & ns & $* * *$ & ns & - & - & - & - \\
\hline \multirow[t]{3}{*}{ Ephemeroptera } & Finland & - & - & - & $\mathrm{ns}$ & ns & $\mathrm{ns}$ & nss \\
\hline & NWSpain & ns & * & ns & ns & ns & ns & nss \\
\hline & MedSpain & ns & ns & ns & - & - & - & - \\
\hline \multirow[t]{2}{*}{ Trichoptera } & Sweden & - & - & - & * & ns & ns & nss \\
\hline & NWSpain & - & - & - & ns & ns & ns & nss \\
\hline \multirow[t]{2}{*}{ Hydrachnida } & NWSpain & - & - & - & $\mathrm{ns}$ & $* *$ & $\mathrm{~ns}$ & nss \\
\hline & MedSpain & - & - & - & $\mathrm{ns}$ & $* *$ & ns & $* * *$ \\
\hline Ephydra & Finland & * & $* * *$ & ns & - & - & - & $\begin{array}{c}(\mathrm{D} / \mathrm{NxN})^{*} \\
-\end{array}$ \\
\hline Odonata & NWSpain & ns & $*$ & $\mathrm{~ns}$ & $\mathrm{~ns}$ & $\mathrm{~ns}$ & $\mathrm{~ns}$ & * \\
\hline Hemiptera & NWSpain & ns & * & $\mathrm{ns}$ & $\mathrm{ns}$ & $\mathrm{ns}$ & ns & $* *$ \\
\hline Orthocladiinae & MedSpain & ns & ns & $* *$ & $* * *$ & $* * *$ & ns & $*$ \\
\hline Chironominae & MedSpain & $*$ & $* * *$ & $\mathrm{~ns}$ & $*$ & $*$ & ns & nss \\
\hline Tanypodinae & MedSpain & ns & ns & $\mathrm{ns}$ & $\mathrm{ns}$ & $* * *$ & $\mathrm{~ns}$ & $* * *$ \\
\hline Pupae & MedSpain & - & - & - & $*$ & $* * *$ & ns & nss \\
\hline
\end{tabular}

$* \mathrm{p}<0.05, \quad * * \mathrm{p}<0.01, \quad * * * \mathrm{p}<0.001, \quad \mathrm{~ns}=$ not significant. Only the significant interactions with D/N are shown. (ANOVAS with transformed data, $\ln$ for densities and biomass, arcsinesqr for proportions and sqr for ratios). 


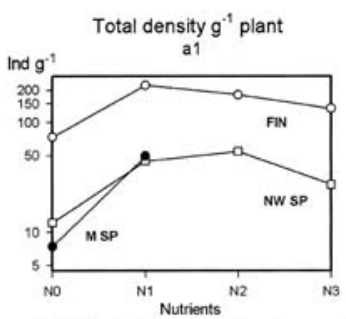

- FIN Vesijärvi, Finland

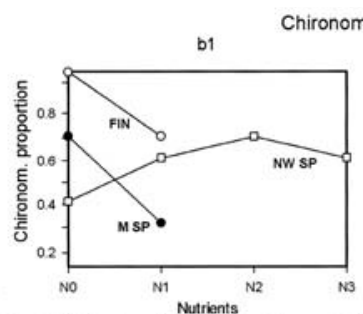

NWSP Sentiz, NW Spain

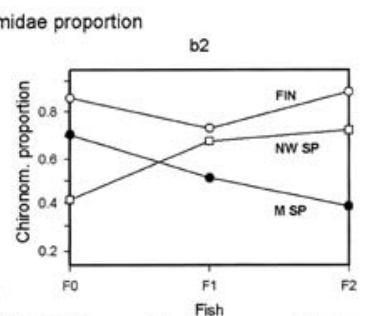

MSP Xeresa, Mediterranean Spain
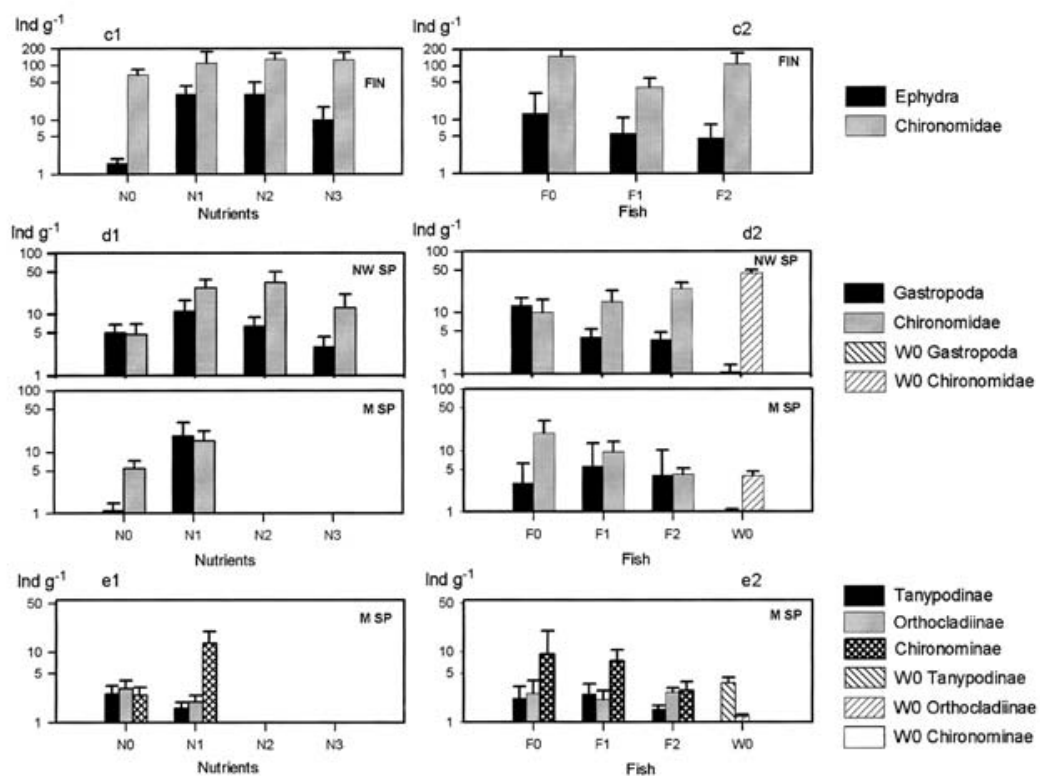

Figure 8. Changes of plant associated macroinvertebrates with respect to nutrient (a1, b1, c1, d1, e1) and fish (b2, c2, d2, e2) treatments from mesocosm experiments carried out in three European locations in 1998. (a1) Means of total density of macroinvertebrates for each location. (b) Means of chironomidae proportion for each location. (c) Means (SE) of densities of ephydrids and chironomids in Vesijärvi (FIN). (d) Means (SE) of densities of gastropods and chironomids in Sentiz (NWSP) and Xeresa (MSP) (e) Means (SE) of densities of three chironomids subfamilies in Xeresa (MSP). Means of 36 mesocoms for pre-treatment week (W0) are also plotted when $>1$. All data log transformed, except (b1) and (b2) where chironomid propotions are arcsine sqr transformed. Cambios de los macroinvertebrados asociados a los macrófitos en relación a los niveles de tratamiento con nutrientes (a1, b1, c1, $d 1$, e1) y peces (b2, c2, d2, e2) llevados a cabo en los mesocosmos experimentales instalados en tres localidades europeas en 1998. (a1) Medias de la densidad total de macroinvertebrados en cada localidad. (b) Medias de la proporción de quironómidos en cada localidad. (c) Medias (ES) de las densidades de efídridos y quironómidos en Vesijärvi (FIN). (d) Medias (ES) de las densidades de gasterópodos y quironómidos en Sentiz (NWSP) y Xeresa (MSP). (e) Medias (ES) de las densidades de tres subfamilias de quironómidos en Xeresa (MSP). Tambien se han representado para los valores $>1$ las medias de los 36 mesocosmos en el momento del pretratamiento (W0). Todos los datos transformados logaritmicamente, excepto (b1) y (b2) a los que se les ha aplicado la transformación arco seno de la raíz cuadrada de la proporción de quironómidos.

ANOVA carried out on plant macroinvertebrate data from 1998 showed that nutrient effects were significant, in most cases (Table 6). As pointed out previously the highest nutrient levels, N2 and N3, provoked the loss of macrophytes in Xeresa (Med Spain) and of fish in the Finnish site. The relationship between macroinvertebrates and nutrients was always (for all locations and all macroinvertebrate groups) a high increase at nutrient level N1 (Fig. 8 a1). This effect also depends on locality and was greater in the Spanish sites. In the sites where all nutrient levels could be analysed, the effects were a saturation curve, with density and biomass increasing at the lowest nutrient addition, levelling off and then diminishing at the highest nutrient level. 
Fish effects on densities (Fig.6, Table 6) were not significant but greatly affected the proportions of the different groups of organisms and thus the effects were significant on biomass and on biomass/density ratio (Table 6). Owing to the different fish species tested, results vary among localities. In the northern sites predation by roach was more detrimental to larger invertebrates (ephydrids and gastropods, among others) than to chironomids (Fig.8 c2,d2). In contrast in Xeresa (Med Spain), Gambusia ate chironomids but not larger invertebrates (such as Physella acuta, the major community component after chironomids, Fig. 8 d2). Thus chironomid proportions (Fig. 8 b2) in Xeresa (Med Spain) varied inversely to Sentiz Lake (NW Spain), because the predation pressure in the benthic major groups was different, Gambusia preyed on chironomids but not gastropods and Condrostoma (Rutilus) arcasii ate gastropods. ANOVA confirmed that the biomass/density ratio decreased significantly with fish in both localities (Post hoc Tukey's tests were significant between absence of fish (F0) and any of the additions)

In Xeresa the different chironomid subfamilies were analysed separately, Chironominae were very scarce in the pre-treatmment week ( $91 \%$ of chironomids were Tanypodinae) but by week 5 became the dominant subfamily ( $76.5 \%$ of total chironomids), mainly composed of Chironomus of greater size than the other subfamilies. Chironominae were significantly depleted by fish predation and enhanced by nutrients (Table 6, Fig. 8e). The other subfamilies did not show any significant differences, but Orthocladinae (12\% of Chironomidae) did increase with nutrients but only in the two fish treatments (significant $\mathrm{F} * \mathrm{~N}$ interaction, Table 6).

\section{9 experiment}

Relative abundances of plant-associated animals (Table 7) in this year differed from 1998, due to different weather conditions, but also to a later start of the experiment. The Finnish lake was much warmer than in 1998 (Table1), but macroinvertebrate abundance was also low. However there was a higher diversity of groups represented and percentage composition was more similar to that of the southern localities in 1998, i.e. it had a higher percentage of gastropods and of Ephemeroptera than the previous year. The Finnish and Swedish sites were similar in their shift from a dominance of chironomids, at the start of the experiment, to a dominance of gastropods and also a greater abundance of other insects (mainly predaceous Polycentropidae and Odonata) after the fifth week. In Sentiz, NW Spain, 1999 was colder than 1998. At the start of the 1999 experiment gastropod percentages were much higher than in 1998, however in Sentiz there was always a preponderance of chironomids and the percentage composition did not vary between 1999 samplings as it did in the northern localities. In Xeresa, the southernmost locality, conditions were very warm and dry in 1999 and chironomids were the dominant group during the whole period (gastropods, abundant in 1998, were practically absent in 1999).

Box plots (Fig. 9) show total densities in day and night samplings performed at the start and

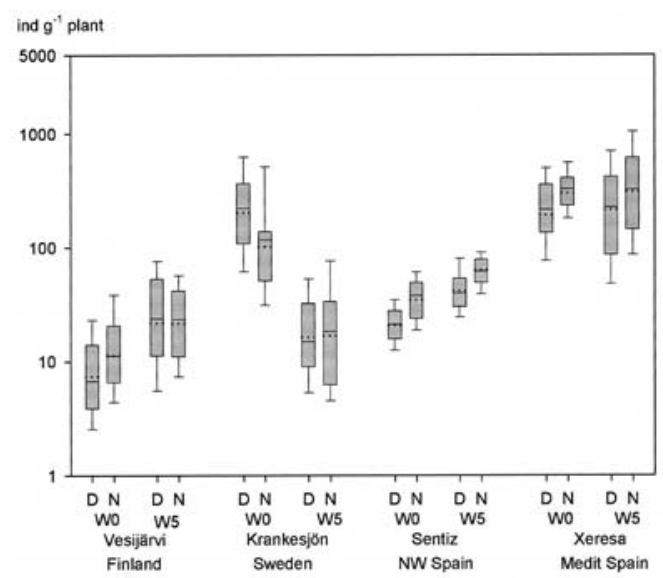

Figure 9. Box plots and whiskers (as in Fig. 1, mean: dotted line, median: solid line) are plotted, of total densities of plant-associated macroinvertebrates in mesocosm experiments carried out at four European locations in 1999. Data, log transformed, are taken from the 36 experimental mesocosms from each locality for the day and night samplings at the pre-treatment (W0) and the fifth week (W5). Diagramas de caja y bigotes (como en la Fig. 1, media: línea discontinua, mediana: línea continua, representando la distribución de los valores de densidad de los macroinvertebrados asociados a los macrófitos en los mesocosmos del experimento conjunto llevado a cabo en 1999 en cuatro localidades europeas. Los datos, con transformación logaritmica, corresponden a los 36 mesocosmos de cada localidad para los muestreos de día y de noche en el momento inicial del experimento (pretratamiento W0) y en la $5^{a}$ semana (W5). 


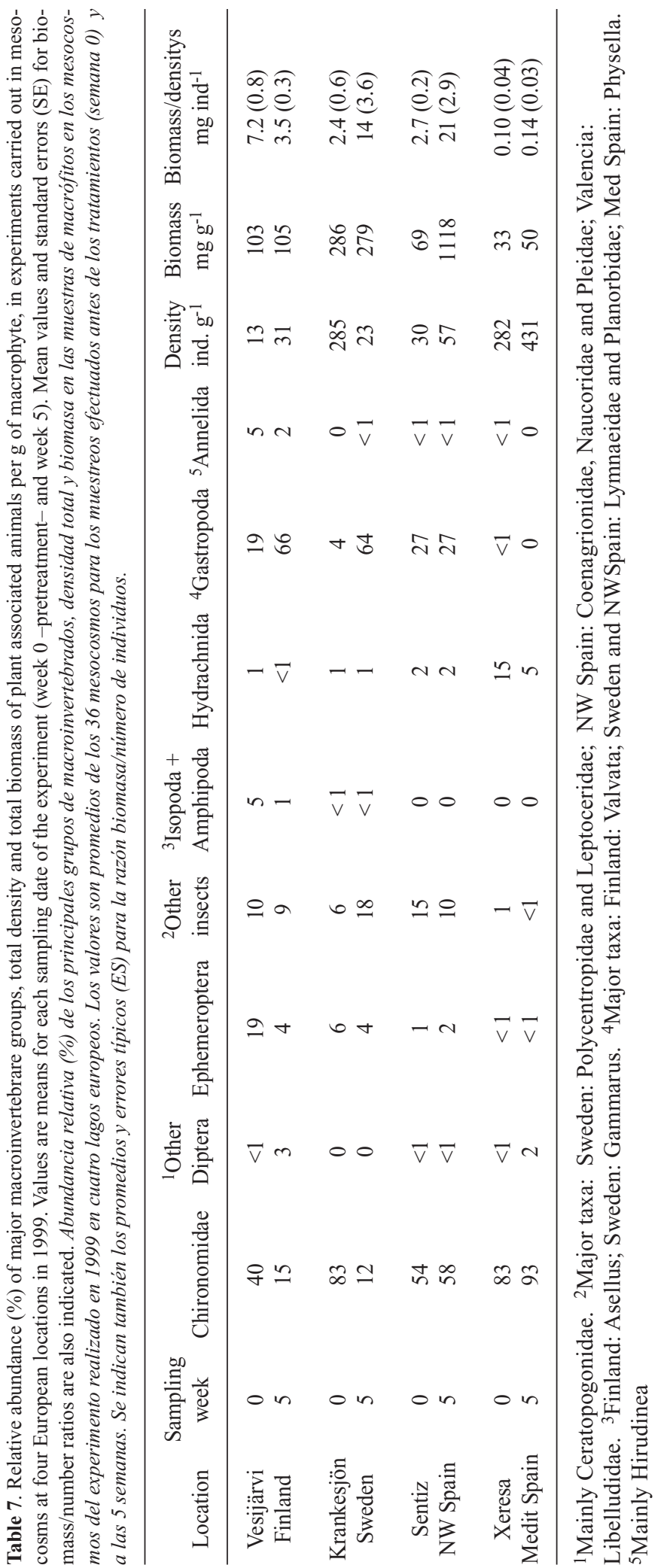




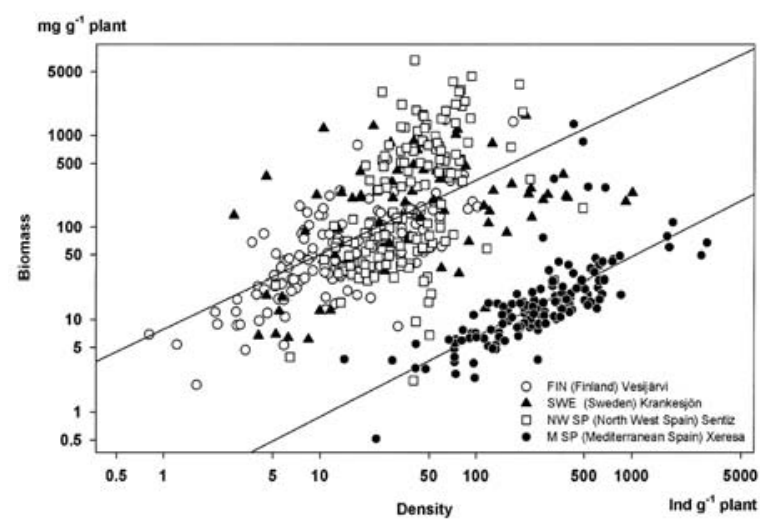

Figure 10. Relationship between total density and biomass of plant-associated macroinvertebrates from mesocosm experiments carried out at four European localities in 1999. Data points from the two sampling dates (week 0 and week 5). Regression statistics with log transformed data: (1) from Xeresa (Med. Sp) b=0.87, $\mathrm{r}^{2}=0.51$ and (2) from the other three locations pooled together $\mathrm{b}=0.81, \mathrm{r}^{2}=0.35$. Relación entre la densidad y la biomasa de los macroinvertebrados de las muestras de macrófitos de los experimentos en mesocosmos realizados en cuatro localidades europeas en 1999. Datos de dos muestreos (semanas 0 y 5). Valores estadísticos de la regresión con los datos transformados logaritmicamente: (1) para Xeresa (Levante Español) $b=0.87, r^{2}=0.51$ y (2) para el resto de las localidades consideradas conjuntamente $b=0.81, r^{2}=0.35$.

in week 5 of the experiment. The two southern countries showed clearly higher numbers in night collections. The Finnish site had very low densities in both samplings, and the slight increase between samplings was mainly due to gastropods, whereas chironomids abundant in 1998, were not so in any of the 1999 samplings. The $5^{\text {th }}$ week sampling in this location was about one month later than in 1998, so it could be that chironomid larva had already matured and emerged. In the Swedish site the diminution observed between the two dates was due to a noticeable chironomid decline (of over $98 \%$ ), which could be also explained by emergence.

The plant-associated community in the southernmost locality, Xeresa was strikingly different than that from the other localities and when biomass and density are plotted together (Fig. 10), it became clearly segregated as a smaller-sized community. These results are clear, although we must take into consideration that biomass measurements could vary among research teams since values were between fresh and dry weight (animals blotted dry in ambient air, see methods) and measurements for smaller animals (minute chironomids) could be nearer the dry weight, thus magnifying the differences.

Results from the ANOVAs (day and night sampling as repeated measures factor, Table 6) show clear differences between the two northern and the two southern sites; nutrients (in much lower and more gradual additions than in 1998) and day/night sampling effects were significant only in the southern localities. On the other hand, responses to fish were significant for most of the variables and very dependent on locality, due to the different fish species used and also to the initial community composition that was subsequently differentially influenced by each fish species.

At lower latitudes there were more individuals sampled at night than by day and differences between day/night samplings were highly significant for total densities, biomass and all arthropod groups (but not in gastropods, three-way ANOVA with repeated measures in one factor, Table 6). In the two northern localities no differences were found. The Fstatistic from one-way repeated measures ANOVA plotted in figure 11 illustrates this further, the higher values in the two Spanish sites (which are highly significant, $\mathrm{P}<0.0001$ ) indicate pronounced differences in day and night distributions of total densities and chironomids, contrasting with the very low non significant $\mathrm{F}$ values obtained in the two northern sites. The effect was specially clear in north western Spain, when one-way ANOVA on each fish treatment were performed separately, a noticeable fish effect was shown, mainly at the low fish level F0 (F-statistics for chironomids were $5.8(\mathrm{p}=0.035), 30.8(\mathrm{p}<0.001)$, and $8.1 \quad(p=0.016)$ respectively for fish levels F0, F1 and F2). In Mediterranean Spain, the effects were much less pronounced and varied depending on the different groups (Fstatistics from fish level $\mathrm{F} 1$ were 16.6 $(\mathrm{p}=0.002), 4.67(\mathrm{p}=0.054)$ and $4.96(\mathrm{p}=0.048)$, respectively for Tanypodinae + Chironominae, Orthocladiinae and total Chironomidae, being lower for the other levels, F0 and F2). 


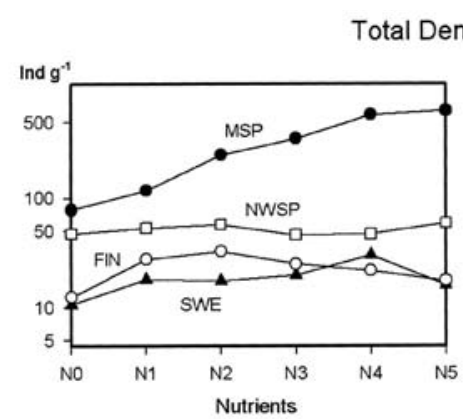

Total Density $\mathrm{g}^{-1}$ plant

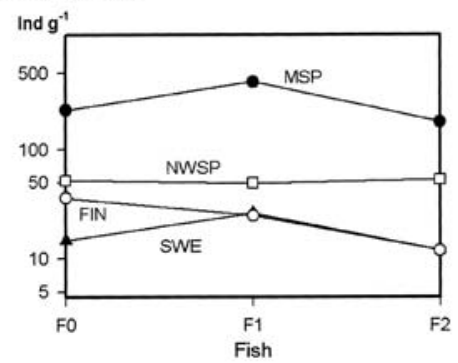

Chiromidae proportion
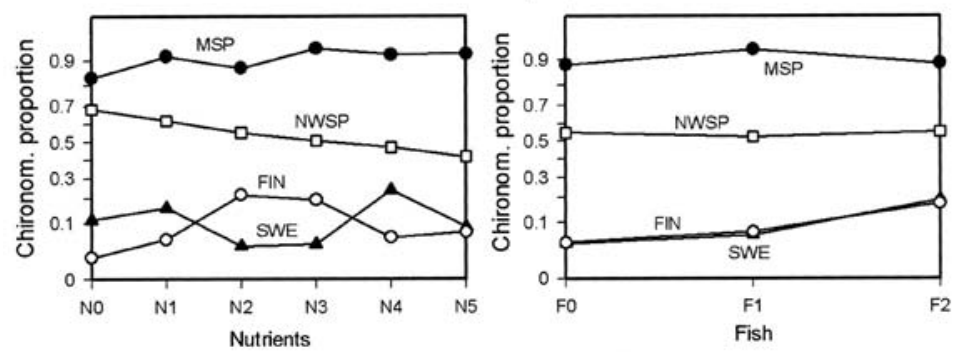

F-Statistic

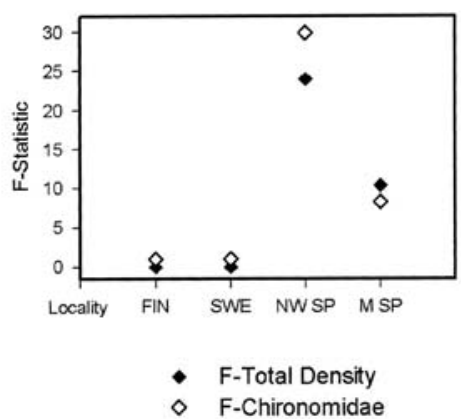

- - FIN (Finland) Vesijärvi

^- SWE (Sweden) Krankesjön

$\rightarrow-$ NW SP (North West Spain) Sentiz

- M SP (Mediterranean Spain) Xeresa

Figure 11. In upper left, means of total density of macroinvertebrates (log transformed data) and in lower panel, the chironomid proportion (arcsine sqr transformed data) in macrophyte samples from mesocosm experiments carried out in four European locations in 1999, with respect to nutrient and fish treatments. F-statistic to test differences between day and night samples from week 5 of total numbers of individuals and chironomid numbers in each locality, obtained from one-way repeated measures ANOVA (upper right). En las figuras de arriba a la izquierda, las medias de la densidad total de macroinvertebrados (datos con transformación logarítmica) y en el panel inferior, las proporciones de quironómidos (datos transformados aplicando el arco seno a la raíz cuadrada de los valores) en las muestras de macrófitos tomadas en los mesocosmos del experimento llevado a cabo en cuatro localidades europeas en 1999, considerando los diferentes niveles de tratamiento de nutrientes y peces. En la gráfica de arriba a la derecha se representan los valores del estadístico $F$ para verificar las diferencias entre las muestras de día y noche tomadas la semana $5^{a}$, aplicando al número total de individuos y al de quironómidos en las distintas localidades, un ANOVA de un factor con medidas repetidas.

Effects of nutrients and fish are shown for density and chironomid proportions in figure 11 and for main groups of organisms in figure 12. In the southernmost site, total densities increased continuously with nutrient additions, reaching a saturation point about nutrient level N4 (1.5 times higher than N1 in the 1988 experiment and less than one third of the N2) and that was the tendency for main groups (Chironomidae and Hydrachnida). Increase of chironomid proportions with nutrients corresponds to the enhanced growth of this group of organisms with fertilization. The high densities of Chironomidae in this site allowed analysis of subfamilies separately. Larvae of Orthocladiinae represented the $94 \%$ of all Chironomidae, $2.5 \%$ were Tanypodinae and $1 \%$ Chirononinae (the remainig $2.5 \%$ were pupae). All subfamilies presented the above mentioned variation, except Tanypodinae which decreased linearly with nutrient increase (as also in 1998, Fig. 12). That may be related to earlier maturation and emergence with fertilization. In Sentiz, the other locality with significant nutrient effects, ANOVA showed high significance on biomass but not on density, because effects (at the low fertilizations tested that year) were higher on larger gastropods and other animals than on the more abundant chironomids (Table 6, Fig. 12). This also resulted in a decrease of chironomid proportions with nutrients (Fig. 11).

The effects of fish in the two northern localities were higher than in the Spanish ones. Fish decreased macroinvertebrate densities at the highest level applied, but not at the low fish level, except in the case of Perca fluviatilis, at the Finnish site, where there was a linear decrease of total density with increasing fish. In Finland, chironomid numbers increased more at nutrient levels N2 and N3, especially when fish were present, and together with heavy preda- 


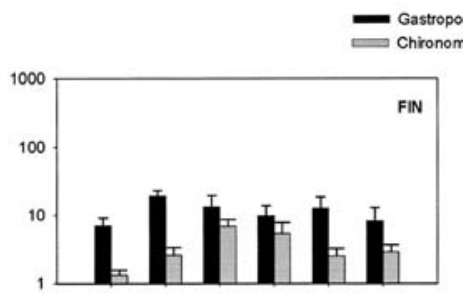

3000 WO Gastropoda
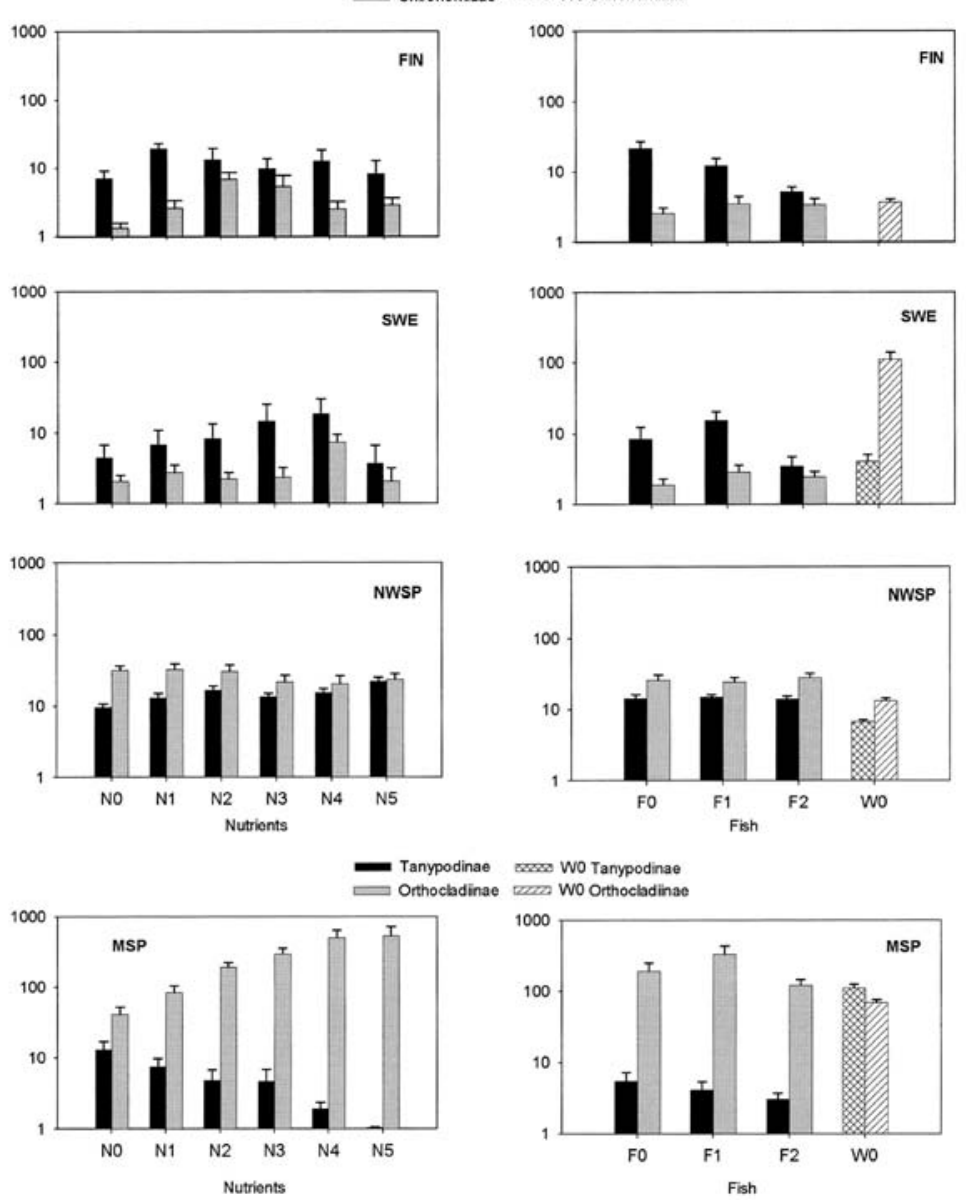

Figure 12. Means of densities (SE) of plant-associated gastropods and chironomids with respect to nutrient and fish treatments in mesocosm experiments carried out in 1999 in four European locations. Chironomidae subfamilies are plotted separately for Xeresa (M Sp, gastropods were negligible). Means of 36 mesocosms for the pre-treatment sampling (W0) are also plotted. Log transformed data. Cambios de las densidades de gastrópodos y quirononómidos asociados a los macrófitos en relación a los niveles de tratamiento con nutrientes y peces llevados a cabo en los mesocosmos experimentales instalados en cuatro localidades europeas en 1998. En Xeresa (M. Sp) se han representado las subfamilias de quironómidos separadamente (no se encontraron prácticamente gastrópodos).

tion on gastropods by Perca at levels F1 and F2 (Figs. 11 and 12), produced higher proportions of chironomids at the intermediate nutrient levels. In Sweden reduction of gastropod numbers by fish was only observed at level F2 and chironomids were most favoured at the highest fish levels. In the Finnish and Swedish mesocosms without fish, the proportion of chironomids was low (Fig. 11) but increased with fish level, whereas it remained higher and relatively steady in the Spanish sites. In the Swedish and Mediterranean Spanish sites there was a positive effect on total density at fish level F1, but then a marked decrease at the high level F2, whereas in Sentiz, NW Spain, no effect was apparent. In Xeresa (Mediterranean Spain) minute chironomids dominated and their proportions, generally around 0.9 , did not vary very much. However when subfamilies are considered separately, fish effects become more conspicuous (Table 6, Fig. 12), Gambusia preyed in the larger Tanypodinae (and also Chironominae, but they were very scarce this year). However the dominant Orthocladiinae reached highest numbers at the low fish - high nutrient combinations (N4-F1 and N5-F1). 


\section{DISCUSSION}

This series of experiments was particularly concerned with latitudinal effects on ecosystem functioning. There was some evidence of different response of macroinvertebrates to nutrient enrichment and fish with latitude but it is difficult to separate climatic effects from confounding factors. Despite this a prominent difference in the southernmost location compared with the others was found. In Xeresa (Med Spain), turbid conditions with subsequent macrophyte disappearance were produced with nutrient addition alone in the 1998 experiments and this is likely to be linked with the much higher temperatures at this site and an inability of zooplankton to control the algal growth (Romo et al., 2004). Thus the minimum level of nutrient associated with a shift to phytoplankton dominance apparently was affected by latitude and suggests a greater response in southern countries to increasing nutrient inputs. In the other localities the effects were not so drastic and macrophytes were maintained.

The results from the 1999 experiment were also very different in the southernmost location, although the level of nutrient applied was much lower and a turbid phase was not produced. A large increase of plant-associated chironomids was observed, relative to other localities. Rates of growth, voltinism and emergence of terrestrial adults are enhanced in warmer countries. The response of macroinvertebrates to nutrient loading was also higher in the second locality in order of latitude, Sentiz (NW Spain), than in the more northern ones, but this was only apparent in the 1998 results. Differential macroinvertebrate responses with latitude have been recorded elsewhere. In southern Florida sites (Rader \& Richarson, 1992) there were clear responses to nutrient additions, but more equivocal ones in northern sites, depending on macrophyte structure, zooplankton and other biotic interrelationships. In Manitoba, Canada, Campeau et al., 1994 found clear responses, but Murki et al. (1994) did not. Fish effects in the present experiments depended on the species tested, but these were just the ones most normally found in each site and in most cases collected from the same or nearby sites.

Several aspects of the results are discussed for the sediment community and the plant-associated one separately. These include changes in the influence of nutrients and fish on both communities in different latitudes; the role of macrophytes in these changes for the sediment community; and the effect of interannual climatic differences on the structure of the plant-associated community.

\section{Sediment macroinvertebrates: Influence of nutrients in different latitudes and the role of macrophytes}

An increase of benthic macroinvertebrate biomass with fertilisation might be expected (Rader \& Richardson, 1992), but it is clear that the relationship has a saturation point and also that there are breakpoints beyond the saturation point, where the system may shift to alternative equilibrium states. The switch from macrophytes to phytoplankton is well established (Moss, 1989; Blindow et al., 1993; Scheffer 1998), but the effects of this on sediment-living animals are not well known. Our results show that the response of the sediment macroinvertebrates to nutrient addition is complex, in line with those from other experiments (Hall et al., 1970; Verdonschot \& Ter Braak, 1994). Each of our studied localities showed different responses, only partly related to latitude. In the northern sites the responses of total biomass or total density to nutrients were less apparent. In Little Mere (UK), a nutrient enriched lake, there was always a high density and changes were very small; in the Finnish locality populations were always very scarce, due to a cold spring and delayed general growth but also in part due to incidental disturbances of the sediment (removal of water lilies and planting Elodea). However the discussion that follows reveals some importance of latitudinal effects.

The general relationship between nutrient addition and total density or biomass was a saturation curve at low nutrient loading, but then at higher nutrient additions the asymptotic maximum declined (Fig. 2). The two southern locali- 
ties had greater slopes. This might be explained by a latitudinal effect related to the higher temperatures and greater increase in phytoplankton in these localities, where the sediment community was completely dominated by chironomids, more dependent on phytoplankton productivity than other zoobenthos (Dermott et al., 1977; Specziar $\&$ Voros, 2001). Furthermore, the number of generations per year (voltinism) increases with temperature (Talling \& Lemoalle, 1998). Thus we might expect higher rates of increase and smaller individual size or biomass especially in Xeresa (Table 2, Fig. 2 e), the warmest locality.

The results from the southernmost location (Med Spain) were very different from those of the other localities. Macroinvertebrate densities and biomass showed a major increase at the lowest nutrient addition, but a clear break point occurred in the relationship and they had low values at the two high fertilisation levels (N2 and N3) by week 5 in 1998 (Fig. 2 a1), when macrophyte communities collapsed and decomposition took place in the sediment. The decreased oxygen conditions in the sediment probably limited the development of chironomids. Chironomid density recovered (in the final sampling week) only in the mesocosms where the highest nutrient treatment (N3) was applied, probably because the high nitrate additions enhanced denitrification. Decomposing material also becomes a better food source after a period of conditioning (Campeau et al., 1994, Suren and Lake, 1989). In week 8 decay of Chara debris was probably more advanced at nutrient level N3 than in N2. In the new situation of N3 mesocosms a rise in chironomids and ephydrids indicated that a new succession was starting in the sediment after the shift into a turbid state.

Changes in community composition with nutrients were significantly different in most localities. In Little Mere, an already eutrophic site, the responses to nutrient additions were very low, with little variation in the already high total biomass or density. In the less fertile localities of Xeresa and Vesijarvi changes were more evident. Chironomid percentages increased at the highest nutrient levels but not at the low nutrient level where the growth of all taxa was stimulated. Ratio of Oligochaeta to chironomids in the Finnish site increased at the low nutrient addition, but not at higher additions (Fig. 5), in accordance with other findings (Verdonschot \& Ter Braak, 1994) that oligochaete abundance declines with high inorganic nutrient additions and also with the general view that oligochaetes are less dependent on phytoplankton production than chironomids, because oligochaetes can use organic materials from other sources (Margalef, 1983).

The influence of macrophytes on the sedimentary benthos can be seen by comparing the results just before ( 5 weeks of treatment) and after ( 8 weeks of treatment) macrophytes were cut. The relationship between total density or biomass and nutrients became more linear when macrophytes were removed. The increase in abundance at the highest nutrient level when the mesocosms had no macrophytes, most notable in southern Spain, was coupled with differences in species composition and lower diversity. Previous studies of natural communities along trophic gradients have shown a decreased diversity, but small changes in abundance of the sediment macroinvertebrates, with higher contents of organic matter in the sediments (Peeters et al., 2004) which may be linked to correspondingly low oxygen levels. When macrophytes were cut, some phytophilous taxa were dislodged to the bottom, and survived mainly in the lower nutrient conditions.

\section{Sediment macroinvertebrates: influence of fish in different latitudes and the role of macrophytes}

The effects of fish were less apparent, but had significance. There were two main opposed effects. Because the fish added were mainly zooplanktivorous, they enhanced growth of macroinvertebrates, perhaps through promoting phytoplankton growth (Beklioglu \& Moss 1996; Scheffer 1991; Moss et al., 2004a) and providing organic excrement to the sediments. On the other hand fish fed on bottom organisms. The first effect was shown by the increased macroinvertebrate densities with fish additions, before macrophytes were cut (week 5), at all 
nutrient levels (Fig. 2 a2). The second effect was observed in the results from week 8 (except in one locality, where Gambusia was tested). Zooplankton became very scarce in the mesocosms with fish, as inevitably did the plantassociated invertebrates, and fish were forced to eat in the now more accessible bottom (Fig. 2 b2). A role of macrophytes in limiting predation on bottom animals by fish is suggested by these results. However there was a clear interaction of the effects of fish with locality after the removal of macrophytes; predatory control was clear where the fish used were young roach, red roach or stikcleback, but not where the fish were Gambusia, which feed more preferentially in the superficial waters. Thus in this latter locality, positive effects of fish on macroinvertebrate biomass and density were noted in the second phase of the experiment as well.

When the taxonomic definition was greater results usually showed further effects, otherwise disguised by pooled data. In Little Mere total numbers of Chironomidae did not vary among treatments, but when subfamilies were analysed separately, fish effects became significant but opposite, after macrophytes were cut; Chironominae were preferentially predated over the smaller Tanypodinae, thus Chironominae decreased whereas Tanypodinae increased in the mesocosms with fish. The success of Tanypodinae, which are carnivorous, depends on the availability of prey, probably favoured by fish. Oligochaetes, although not significantly, were more abundant in mesocosms with fish and fish activity in removing sediment could facilitate the encounter of prey.

Fish influenced overall the community composition, thus a ratio often used as an indicator of trophic level (Oligochaeta/Chironomidae) was affected by presence of fish, especially in absence of macrophytes. Chironomids, living closer to the sediment surface than oligochaetes, are easier to prey on. The ratio depends also on the components of the chironomid community, usually of different sizes and differentially predated by fish, as has been illustrated with the Little Mere data. Hall et al. (1970) found also that fish increased the percentage of small organisms but their effects showed strong inter- actions with nutrients, the most striking effects being observed at lower nutrient levels. In our experiments also the negative effects of fish on prey species, in all cases, were more striking in the low nutrient mesocosms.

\section{Plant-associated macroinvertebrates: influence of nutrients at different latitudes and the role of climate}

For plant-associated macroinvertebrates, the effects of nutrients clearly differed according to latitude, as they did for sedimentary benthos. The southernmost and warmest lake was the more strikingly different. Here the high nutrient additions in 1998 led to turbid conditions and the subsequent macrophyte decay cause loss of plant-associated fauna in the mesocosms with high nutrients (N2 and N3). The moderate nutrient additions in 1999 did not caused excessive phytoplankton development and the clear phase was maintained, but it was a very dry year which led to an explosive growth of minute Orthocladiinae and a restrained growth of other macroinvertebrates. The year's climate was important in determining the numbers and also the presence of some groups of organisms, especially the gastropods. A cold year with a delay in macrophyte growth in northern countries (Finnish site) or a very dry year (Mediterranean Spanish site) prevented the development of their populations at the time of the experiment.

The same saturation relationship between macroinvertebrate density and biomass and nutrient enrichment, described for the sediment community, was found in the plant-associated community. The saturation points varied depending on the different taxa and localities. In general, they were reached at additions below N3 in 1999, approximately like N1 in 1998, except in Xeresa, Mediterranean Spain, where they were reached between $\mathrm{N} 4$ and N5. Here again there were also differential break points for different taxa, and total densities could increase or decrease with different species composition. The results are complex because habitat requirements and life history parameters will influence the response of each taxon to changes in food. 
Plant-associated chironomids may eat detritus and/or epiphytic alga, but some species can derive most of their nutrition from the water column (Berg, 1950) and still others may be free-living predators. Despite the differences in food habits, emergence of the diverse groups of chironomids was greatly affected by fertilisation. Campeau et al. (1994), using experimental enclosures placed in a wetland, found that emergence of several chironomid subfamilies occurred earlier in the nutrient enriched enclosures than in the untreated ones, and they estimated that total numbers of Tanypodinae and Orthocladinae emerging were positively affected by fertilisation. Ward \& Cummings (1979), studying a stream chironomid, suggested also that quantity and quality of food could affect the number of generations per year. Thus accelerated emergence in highly fertilised mesocosms could imply earlier declines of chironomids in them.

On the other hand, as indicated for sediment invertebrates, voltinism is enhanced by temperature. This might explain why, in more northern latitudes, we found a greater diminution of chironomid densities between the pre-treatment and the fifth week, due to emergence and delayed colonisation, compared with the two Spanish sites, where a superposition of generations could occur. This was especially clear in the warmest locality, Xeresa, where chironomids were very small (small biomass to numbers ratios), with a large proportion of first instars, thus indicating the shortness of generation time. Seasonality is also an important factor. In Xeresa, the dominant subfamily in the fifth week was Orthocladiinae, whereas in the pretreatment week Tanypodinae were more abundant. In this locality multivoltinism of Orthocladinae could account for the observed continuous increase in density with nutrients.

In the other Spanish site, Sentiz the total number of chironomids increased also with time, whereas in the two northern sites there was a marked decline (observed in the 1999 experiment because we had no data in 1998 from Sweden and only the final sampling from Finland). In northern countries, the number of generations per year must be lower and re-colo- nisation after emergence much slower, thus in the northern sites, as the season advances chironomids diminish and other groups become dominant, whereas in the two Spanish localities chironomid larvae were always the major group.

Life history parameters are also important in other groups of organisms. Osenberg (1989) noted that snails responded to increased food either by increase in number or in body growth, depending on the timing of fertilisation relative to their reproduction. Our results show that the presence of snails depends on the year and thus on interannual weather differences. When present they increased in all localities from the pretreatment to the fifth week and much more in the fertilised mesocosms. However ANOVAs showed varied significance between years, and probably among species involved. In 1998 the effect was significant, with a marked positive increase at low nutrient levels (N1). In the warmer 1999, snails dominated in the samples of northern countries and were the second main group in $\mathrm{N}$ W Spain, but although we did not find significant increases in density with nutrients, we found it for total biomass, to which snails made a substantial contribution, indicating a body growth response in this group of organisms.

\section{Plant-associated macroinvertebrates: influence of fish species characteristic from each location}

Fish effects were significant when total densities or biomasses were examined and the effect depended on the fish densities applied. Direct effects of reduction by predation of macroinvertebrate densities were observed in all sites particularly at the high-density level F2, but the resulting macroinvertebrate group proportions differed among sites mostly because of subtle differences in the feeding behaviour of the fish species tested. These were selected from the most common in each latitudinal location.

On the other hand, through the reduction of open-water microcrustaceans by fish, phytoplankton increases and/or changes in community composition could increase numbers of chironomids that depend on fineorganic matter. It has 
also been suggested that the resulting dominance of small zooplankton, with higher metabolic rates, increases recycling of nutrients (Vanni, 1996), which could also enhance epiphytic growth especially at low nutrient additions and increase the numbers of plant-associated grazers. Fish metabolism and excrement could also have some effects on recycling of nutrients and on detritus pathways. Moreover fish could also have a cascading effect and, by eating some grazers, increase epiphytic growth (Brönmark and Vermaat 1998) favouring other grazers. Fish could also reduce some of the invertebrate predators. All these are confounding factors that could not be separated in our experiments. The different fish species used also complicated the results as discussed above.

Thus there is a counterbalance between effects of fish as direct predators and indirect positive effects. However at high fish densities mortality by fish predation is usually greater and the overall result is a diminution of their prey. In the northern localities, gastropods were the dominant group in 1999 and they showed higher abundances and proportions in the fishless mesocosms than in the mesocosms with fish, thus indicating that in these localities fish also depressed gastropods. This effect was prominent at any fish level when Perca fluviatilis was the fish added, but not with Rutilus rutilus where it was only clear at high fish level (Figs. 11 and 12). Our results suggests also that when the fish added are Rutilus or especially, Perca, which prey preferentially on bigger-than-chironomids plant-associated animals, they may enhance the growth of chironomids because they stimulated periphyton development (Hietala et al., 2004). The effects of Chondrostoma arcasi, in Sentiz, NW Spain, were not so clear and depended on the year. In 1998 there was a clear decrease of gastropods and an increase of chironomid proportion with fish but not in 1999. A possible explanation is that the warmer conditions in the second year promoted an earlier growth of gastropods (Tables 5 and 7, Fig. 12), which were already too big to eat when the experiment began. In this location in 1999, proportion of chironomids did not vary with fish but decreased with nutrients, thus effects were contrary to those of 1998. On the other hand, in the southernmost locality, Xeresa, Gambusia preyed on plant-associated chironomids, but not gastropods and the later were favoured in the mesocosm with fish in 1998. However in the very dry 1999 conditions in this location, gastropods were practically absent and the chironomid community was completely different from the previous year. There was an explosive growth of Orthocladiinae (Chironominae, abundant in 1998, were very scarce). Since our results indicate that fish preyed preferentially on larger and more motile taxa than on the dominant minute orthocladiinae, we found in 1999 a clear increase of chironomids at the low fish level (but their reduction at high fish densities). In 1998 enhancement of chironomids at low fish level was not observed, because in that year chironomid densities were much lower and our results indicate that fish preyed on the dominant subfamily Chironominae.

Finnally day/night samplings indicated that plant-associated macroinvertebrates show a higher nocturnal activity and migration towards the surface in summer. This is very well known for zooplankton, but less studied in plant-associated animals. A latitudinal effect is expected because of short periods of darkness in the summer nights of northern latitudes and our results that differential day/night distribution was more marked in the southern latitudes. However this depends also very much on the species studied. Moreover there were greater numbers sampled at night when fish were present than when they were not but basicaly at low density of fish this could further confirm the hypothesis that the different day/night distribution found was due to migration to cope with fish predation.

All the above discussed results indicate that the impact of fish is much more important in the composition of the plant-associated community than in their abundance and that the outcome of the interaction depends greatly on the climatic conditions, which determine the life history traits of the macroinvertebrates. Moreover the effects of fish depend greatly on their density. In some cases macroinvertebrate densities increased at low fish densities (chironomids as well as 
gastropods) which could result in control of epiphytes and maintenance of macrophytes. This suggests that in macrophyte-dominated shallow lakes, "zooplanktivorous" fish (which may often eat macroinvertebrates) abundances are central, not only in structuring planktonic communities, but also in the littoral-pelagic coupling through complex interactions and feedback mechanisms in food webs.

Our overall conclusion therefore is that latitudinal influences on the structure of the macroinvertebrate communities are present but that they operate indirectly. There is a prominent effect of nutrients on these communities so that starting trophy is very important. Fish effects are layered on these and depend to a large extent on the particular range of diet of the species involved.

\section{ACKNOWLEDGEMENTS}

We are very grateful to all the other participants in the SWALE research project. We specially thank Antonio Picazo and Juan Miguel Soria for computer assistance in the elaboration of figures. We are also thankful to the European Union for providing funds under contract ENV4-CT97-04020.

\section{REFERENCES}

BEKLIOGLU, M. \& B. MOSS. 1996. Mesocosm experiments on the interaction of sediment influence, fish predation and aquatic plants with the structure of phytoplankton and zooplankton communities. Freshwat. Biol., 36: 315-325.

BERG, C. O. 1950. Biology of certain Chironomidae reared from Potamogeton. Ecol. Monogr., 20: 83-101.

BLINDOW, I., G. ANDERSSON, A. HARGEBY, \& S. JOHANSON. 1993. Long term pattern of alternative stable states in two shallow eutrophic lakes. Freshwat. Biol., 30: 159-167.

BRÖNMARK, C. \& J. VERMAAT. 1998. Complex fish-snail ephiphyte interactions and their effects on submerged freshwater macrophytes. In: The structuring role of submersed macrophytes in lakes. E. Jeppesen, Ma. Sondergaard, Mo. Sondergaard \& K. Christoffersen (eds.): 47-69. Springer Verlag, New York.
CAMPEAU, S., H. R. MURKIN \& R. D. TITMAN. 1994. Relative importance of algae and emergent plant litter to fresfwater marsh invertebrates. Can. J. Fish. Aquat. Sci., 51: 681-692.

DE MOTT, R. M., J. KALFF, W. C. LEGGET \& J. SPENCE. 1977. Production of Chironomus, Procladius and Chaoborus at differnt levels of phytoplankton biomass in Lake Memphremagog, QuebecVermont. J. Fish. Res. Board Can., 34: 2001-1007.

FERNÁNDEZ-ALAEZ, M., C. FERNÁNDEZ-ALAEZ, E. BÉCARES, M. VALENTIN, J. GOMÁ \& P. CASTRILLO. 2004. A 2-year experimental study on nutrient and predator influences on food webs in a shallow lake of north-west Spain. Freshwat. Biol., 49: 1574-1592.

HALL, D. J., W. E. COOPER \& E. E. WERNER. 1970. An experimental approach to the production dynamics and structure of freshwater animal communities. Limnol. Oceanog., 15: 839-928.

HANSSON, L.-A., M. GYLLSTROM, A. STÅHLDELBANCO \& M. SVENSSON. 2004. Responses to fish predation and nutrients by plankton at different levels of taxonomic resolution. Freshwat. Biol., 49: 1538-1550.

HIETALA, J., K. VAKKILAINEN \& T. KAIRESALO. 2004. Community resistance and change to nutrient enrichment and fish manipulation in a vegetated lake littoral. Freshwat. Biol., 49: 1525-1537.

IWAKUMA,T., H. HAYASI, I. YASUDA, T. HANAZATO \& K. TAKADA. 1990. Impact of whitefish on an enclosure ecosystem in a shallow eutrophic lake. Hydrobiologia, 200/201: 141-152.

JEPPESEN, E., MA. SONDERGAARD, MO. SONDERGAARD \& K. CHRISTOFFERSEN (Eds.) 1998. The structuring role of submersed macrophytes in lakes. Springer Verlag, New York, 423 pp.

KORNIJÓW, R. 1998. Quantitative sampler for collecting invertebrates associated with submersed and floating-leaved macrophytes. Aquat. Ecol., 32: 241-244.

MARGALEF, R. 1983. Limnología, Omega, Barcelona, $1010 \mathrm{pp}$.

MCQUEEN, D. J., J. R. POST \& E. L. MILLS. 1986. Trophic relationships in freshwater pelagic ecosystems. Can. J. Fish. Aquat. Sci., 43: 1571-1581.

MOSS, B. 1989. Water pollution and the management of ecosystems: a case study of science and scientist. In: Toward a more exact Ecology. P. J. Grubb \& J. H. Whittaker (eds.): 401-422. Blackwell Scientific, Oxford.

MOSS, B. (Ed.) 2004. Fish and nutrient effects in shallow lakes: a pan European mesocosm experiment. Freshwat. Biol., special issue 49(12): 1517-1656. 
MOSS, B., D. STEPHEN, D. BALAYLA, E. BÉCARES, S. E. COLLINGS, C. FERNÁNDEZALÁEZ, M. FERNÁNDEZ-ALÁEZ, C. FERRIOL, P. GARCÍA, J. GOMÁ, M. GYLLSTRÖM, L.-A. HANSSON, J. HIETALA, T. KAIRESALO, M. R. MIRACLE, S. ROMO, J. RUEDA, V. RUSSELL, A. STÅHL-DELBANCO, M. SVENNSON, K. VAKKILAINEN, M. VALENTIN, W.J. VAN DE BUND, E. VAN DONK, E. VICENTE \& M.J. VILLENA. 2004. Continental-scale patterns of nutrient and fish effects on shallow lakes: synthesis of a pan-European mesocosm experiment. Freshwat. Biol., 49: 1633-1649.

MURKIN, H. R., J. B. POLLARD, M. P. STAINTON, J. A. BOUGHEN \& R. D. TITMAN. 1994. Nutrient additions to wetlands in the Interlake region of Manitoba, Canada: effects of periodic additions throughout the growing season. Hydrobiologia, 279/280: 483-495.

OSENBERG, C. W. 1989. Resource limitation, competition and the influence of life history in a freshwater snail community. Oecologia, 19: 512-519.

PATRIARCHE, M. H. \& R. C. BALL. 1949. An analysis of the bottom fauna production in fertilized and unfertilized ponds and its utilization by young-ofthe-year fish. Technical Bulletin Michigan State University Agriculture Experimental Station, Section Zoology, 207, 35 pp.

PEETERS, E. T. H. M., R. GYLSTRA \& J. H. VOS. 2004. Benthic macroinvertebrate community structure in relation to food and environmental variables. Hydrobiologia, 519: 103-115.

RADER, R. B. \& C. J. RICHARSON. 1992. The effects of nutrient enrichment on algae and macroinvertebrates in the everglades: a review. Wetlands, 12: 121-135.

ROMO, S., M. R. MIRACLE, M. J. VILLENA, J. RUEDA, C. FERRIOL, \& E. VICENTE. 2004. Mesocosm experiments on nutrient and fish effects on shallow lake food webs in a Mediterranean climate. Freshwat. Biol., 49: 1593-1607.

SANDILANDS, K. A., B. J. HANN \& L. G. GOLDSBOROUGH. 2000. The impact of nutrients and submersed macrophytes on invertebrates in a prairie wetland, Delta March, Manitoba. Arch. Hydrobiol., 148: 441-459.

SCHEFFER, M. 1991. Fish and nutrients interplay determines algal biomass: a minimal model. Oikos, 62: 271-282.
SCHEFFER, M. 1998. Ecology of Shallow Lakes. Chapman \& Hall, London, 357 pp.

SPECZIAR, A. \& L. VOROS. 2001. Long-term dynamics of Lake Balaton's chironomid fauna and its dependence on the phytoplankton production. Arch. Hydrobiol., 152: 119-142.

STEPHEN, D., T. ALFONSO, D. BALAYLA, E. BÉCARES, S. E. COLLINGS, M. FERNÁNDEZALÁEZ, C. FERNÁNDEZ-ALÁEZ, C. FERRIOL, P. GARCÍA, J. GOMÁ, M. GYLLSTRÖM, L.-A. HANSSON, J. HIETALA, T. KAIRESALO, M. R. MIRACLE, S. ROMO, J. RUEDA, A. STÅHLDELBANCO, M. SVENSSON, K. VAKKILAINEN, M. VALENTÍN, W. J. VAN DE BUND, E. VAN DONK, E. VICENTE, M. J. VILLENA \& B. MOSS. 2004. Continental-scale patterns of nutrient and fish effects on shallow lakes: introduction to a pan-European mesocosm experiment. Freshwat. Biol., 49: 1517-1524.

STEPHEN, D., D. BALAYLA, S. E. COLLINGS \& B. MOSS. 2004. Two mesocosm experiments investigating the control of summer phytoplankton growth in a small shallow lake. Freshwat. Biol., 49: 1551-1564.

SUREN, A. M. \& P. S. LAKE. 1989. Edibility of fresh and decomposing macrophytes to three species of freshwater invertebrate herbivores. Hydrobiologia, 178: $165-178$.

TALLING, J. F. \& J. LEMOALLE. 1998. Ecological dynamics of tropical inland waters. Cambridge University Press, Cambridge, $441 \mathrm{pp}$.

VAN DE BUND, W. \& E. VAN DONK. 2004. Effects of fish and nutrient additions on food-web stability in a charophyte-dominated lake. Freshwat. Biol., 49: 1565-1573.

VANNI, M. J. 1996. Nutrient transport and recycling by consumers in lake food webs: implications for algal communities. In: Food webs. Integration of patterns and dynamics. G. A. Polis \& K. O. Winemiller (eds.): 81-95. Chapman \& Hall, London.

VERDONSCHOT, P. F. M. \& C. J. F. TER-BRAAK. 1994. An experimental manipulation of oligochaete communities in mesocosms treated with chorpyrifos or nutrient additions: multivariate analyses with Monte Carlo permutation tests. Hydrobiologia, 278: 251-266.

WARD, G. W. \& K. W. CUMMINGS. 1979. Effects of food quality on growth of a stream detritivore, Paratendipes albimanus (Meigen) (Diptera: Chironomidae). Ecology, 60: 57-64. 